\title{
PRESIDENTIAL PREROGATIVE UNDER THE CONSTITUTION TO DEPLOY U.S. MILITARY FORCES IN LOW-INTENSITY CONFLICT
}

\author{
MARK T. UYEDA
}

As applied to the United States, small wars are operations undertaken under executive authority, wherein military force is combined with diplomatic pressure in the internal or external affairs of another state whose government is unstable, inadequate, or unsatisfactory for the preservation of life and of such interests as are determined by the foreign policy of our Nation. ${ }^{1}$

\section{INTRODUCTION}

The dividing line between a state of war and a state of peace has never been clear. Between the two concepts lies the realm of the sinall war, or in present-day vernacular, the low-intensity conflict (LIC). ${ }^{2}$ Historically, U.S. inilitary forces have been deployed around the world under circumstances that can be classified as LIC. ${ }^{3}$ The President has often used military forces for missions

1. U.S. MARINE CORPS, SMAll WARS MANUAL ch. 1, I 1-1 (1940).

2. As the former NATO Supreme Allied Commander, Europe, remarked, "When we think about the possibilities of conflict we tend to invent for ourselves a comfortable vision of war, a theater with battlefields we know, [and] conflict that fits our understanding of strategy and tactics ...." John R. Galvin, Uncomfortable Wars: Toward a New Paradigm, in UNCOMFORTABLE WARS 9, 9 (Max G. Manwaring ed., 1986). However, LIC, in the form of "[s]urrogate war, general violence, subversive activity, multiplication of small wars, [and] widespread training of terrorists," has intruded on the traditional vision of war (i.e., high-intensity warfare) and thus has been set aside to the "periphery of warfighting" by the military. Id. at 11-12.

3. Until the creation of more specialized unconventional warfare units and the regular forward deployment of U.S. Army and Air Force units abroad during the Cold War, LIC operations usually involved U.S. Navy and Marine Corps forces, because they were generally the only units readily available to undertake such missions. See Ronald Schaffer, The 1940 Small Wars Manual and the "Lessons of History," MiL. AFr., Apr. 1972, at 46, 46. The Marines can be described generically as naval infantry and are regularly deployed aboard U.S. Navy warships. Between 1800 and 1934, Marine Corps units conducted 180 landings in 37 different countries. U.S. MARINE CORPS, supra note 1 , ch. 1, II 1-1. In a post-Cold War return to the past, the U.S. Navy and Marine Corps have refocused their mission away from the neutralization of Soviet naval threats to the projection of U.S. military power in regional crises and conflicts. See Robert Holzeo, 'From the Sea' Challenges U.S. Navy to Adapt, DEF. NEwS, Aug. 15, 1994, at 10; John Luddy, Charting 
that cannot be clearly labeled as war; under such circumstances, military forces have been deployed due to some intrinsic or unique capability, availability, or convenience in order to further U.S. foreign policy. ${ }^{4}$

Witl the demise of the Soviet Umion and thus of the likelihood of a higl1-intensity conflict between conventional forces, the LIC lias come to the forefront of instances in which U.S. unilitary forces will be used as imstruments of U.S. foreign policy. LIC will be seen no longer as primarily a Cold War tactic used to limit Soviet expansionism in the Third World, but rather as a separate approaclı to inplementing foreign relations. As sucl, LIC can be used to stabilize the international order and enlance the economic and national security of the United States. Recent U.S. military involveinent abroad lias underscored the nnportance of LIC in foreign affairs.

The purpose of this Note is to examine the President's constitutional authority to deploy military elements into hostile or potentially hostile situations in order to further U.S. economic, diplomatic, or security interests without infringing on congressional powers. This Note analyzes the constitutional separation of powers as it pertains to LIC and attempts to reconcile the original intent of the Framers with the historical and customary use of military power by the President in light of the contemporary global threat

a Course for Navy in the 21st Century, Heritage Found. Rep., Mar. 9, 1994, available in LEXIS, News Library, Nwltrs File.

4. Recent exanples include the 1987 U.S. Navy-escort of reflagged Kuwaiti tankers in the Persian Gulf; the 1989 air-to-air engagement by U.S. Navy aircraft with Libyan fighters over the Mediterranean Sea 70 miles north of Libya; the 1989 deployment of military and Special Forces advisors to Colombia, Bohivia, and Peru to provide assistance in counternarcotics operations; the 1989 sorties by U.S. Air Force fighter aircraft to provide combat air patrol during a rebel coup attempt against the Aquino government in the Philippines; the 1990 deployment of a reinforced Marine rifle company to protect the U.S. embassy in Liberia and evacuate U.S. citizens; the 1990 deployment of defensive troops in Saudi Arabia in Operation Desert Shield; the use of U.S. Air Force C-141 transports in 1991 to carry Belgian and French troops to Zaire in the wake of widespread looting and rioting; the 1992 evacuation of U.S. citizens from Sierra Leone after a military coup against the local government; the 1992 deployinent of humanitarian assistance in Solnalia during Operation Restore Hope; the 1993 use of U.S. forces in BosniaHerzegovina to airdrop relief supplies and enforce a no-fiy zone; the 1993 deployinent of 350 U.S. soldiers for peacekeeping operations in Macedonia to maintain stability in an area of the former Yugoslavia; the 1994 humanitarian assistance operation in Rwanda; and the 1994 intervention in Haiti in Operation Uphold Democracy. See ELLEN C. CoLLIER, INSTANCES OF USE OF UNITED STATES ARMEd FORCES ABROAD, 1798-1993, at 20-23 (Congressional Research Service, CRS Report No. 93-890 F, 1993). 
environment. Part I reviews various attempts to define LIC, a concept that has only recently been recognized as a separate doctrinal approach to conflict and foreign relations. Part II examines the constitutional balance of power between Congress and the President regarding LIC and argues that in the absence of explicit congressional legislation, the President has authority under the Constitution to deploy U.S. armed forces im LIC in order to effectuate U.S. foreign relations. ${ }^{5}$

By examining the LIC mission as an independent, doctrinal approach to conflict, this Note implicitly rejects the defensive/offensive theory and adopts the threshold approach for analyzing constitutional war powers. This Note imcorporates the development of LIC theory in the academic and operational areas of national security as providing a sufficient framework under which constitutional analysis can occur. In distinguishing between low-, mid-, and high-intensity warfare, this Note argues that LIC should be treated differently from the other levels of conflict for constitutional purposes, inasmuch as the President has imdependent authority to engage in LIC in the absence of explicit, specific congressional action to the contrary. ${ }^{6}$ While the thresliold theory does liave certain drawbacks, most notably the definitional problein of LIC, it is superior to the defensive/offensive theory as an instruinent to analyze the constitutional separation of powers.

\section{DEFINING LOW-INTENSITY CONFLICT}

The full spectrum of modern LIC methods includes uses of military force that were uncommon before the twentieth century. ${ }^{7}$

5. This Note also argues for an interpretation of the Constitution extending presidential authority to engage in LIC in the absence of authorization from the United Nations or any other international governmental organization. Thus, because this Note argues that the President holds a prerogative to engage U.S. military forces in LIC without prior congressional authorization, it does not address the question of whether congressional ratification of the U.N. Charter confers some form of approval to the President to use the military when employed pursuant to U.N. authority.

6. This Note presumes for the purposes of analysis that congressional authorization would be required before the President could commence a mid- or high-intensity conflict. However, this Note expresses no opinion as to the constitutional authority of the President to engage in conflicts that exceed low-intensity in the absence of congressional approval.

7. KALEVI J. HoLSTI, PEACE AND WAR: ARMEd CONFLICTS AND INTERNATIONAL ORDER 1648-1989, at 271-72 (1991). Holsti observed that "[a]s the balance between costs, risks, and advantages has shifted with the development of weapons of mass destruc- 
In contrast to the eighteenth and nineteenth centuries, when nation-states essentially had an all-or-nothing choice between diplomacy and war in their pursuit of foreign relations, this century has seen the development of numerous LIC techmiques so that a country may obtain its desired objectives without resort to war. ${ }^{8}$ Thus, "[a] typical foreign policy problem facing many governments today is to find that mix of activities that will achieve or defend purposes or settle issues short of the overt and massive use of military power." Furthermore, the use of war and naked aggression as a legitimate instrument of foreign policy to achieve a desired end has been restricted by the U.N. Charter. ${ }^{10}$

In the United States, the Marine Corps' Small Wars Manual was the first comprehensive recognition of LIC, incorporating all

tion, the menu of policy alternatives to war has expanded." Id. at 271. Thus, war is no longer "a single institution of the states system," and military confrontations between states do not occur exclusively through the traditional conflict between two or more organized armies. Id. at 272 .

8. See id. at 271-72.

9. Id. at 272. While in earlier centuries war could be considered a conflict or engagement between nation-states, that presumption no longer holds for the post-World War II era:

[T] he forms of armed combat have diversified to the point where we can no longer speak of war as a single institution of the states system. Few formalities (declarations of war) are exchanged, the identity of parties employing force is not always easy to establish, many civil wars have become internationalized, and some military actions do not conform to the traditional idea of two or more organized armies fighting against each other. If war was once an institution in the sense that it had estabhished norms, rules, etiquettes, and standardized strategies and tactics, that is no longer the case today.

Id. Thus, if one considers war in the classical sense (i.e., between nation-states) and armed intervention to be separate and distinct doctrines regarding the use of military force, then one finds that the nature of conflict has changed dramatically in the 20th century: the number of classical wars has declined, while the number of armed interventions has increased. Id. at 273.

10. "All members shall refrain in their international relations from the threat or use of force against the territorial integrity or political independence of any state, or in any other manner inconsistent with the Purposes of the United Nations." U.N. CHARTER art. 2, T 4. The only legal exceptions to the general prohibition against war are when the war is pursuant to an enforcement action authorized by the Security Council, id. art. 42, or is part of individual or collective self-defense, $i d$. art. 51.

Efforts have also been made in international law to establish the principle of nonintervention, which "purports to prohibit political, psychological, economic and military intervention." WilliaM V. O'BRIEN, LAW AND MORALITY IN ISRAEL'S WAR WITH THE PLO 90 (1991). However, the principle of nonintervention has not been accepted as absolute, and several broad exceptions have been identified, including intervention by treaty right, intervention by invitation of an incumbent government, intervention to protect and evacuate nationals and others endangered in a civil war, and humanitarian intervention to protect people from their own tyrannical government. Id. at 90-91. 
U.S. experience in LIC prior to World War II. ${ }^{11}$ It represented the first comprehensive study of LIC as a warfighting doctrine separate from the more conventional, European-style land war. ${ }^{12}$ During the period before World War II, U.S. military units had engaged in LIC actions in China, the Philippines, the Caribbean, Latin America, and North America. ${ }^{13}$ The Small Wars Manual concluded that "[s]mall wars vary in degrees from smiple demonstrative operations to military intervention in the fullest sense, short of war" and that there "1nay be found an infinite number of forms of friendly assistance or intervention which it is almost impossible to classify under a limited number of individual types of operations."14

\section{A. LIC as Part of U.S. Foreign Policy Doctrine}

Since the end of World War II, U.S. foreign policy has been priniarily concerned with the containment of Soviet expansionism and the prevention of nuclear or large-scale conventional war. ${ }^{15}$ Hence, LIC generally has been perceived as an instrument, apphied both by the West and the Soviets, to be used when more direct means are unable to achieve desired policy objectives. ${ }^{16}$ Interestingly, it has been hypothesized that the deterrence effect of nuclear weapons during the Cold War encouraged the use of LIC by ehinniating mid- and high-intensity warfare as viable pohicy alternatives. ${ }^{17}$

11. Schaffer, supra note 3 , at 46 .

12. Id.

13. Id.

14. U.S. MARINE CORPS, supra note 1, ch. 1, I 1-1.

15. See generally STEPHEN E. AMBROSE, RISE TO GlOBALISM (4th rev. ed. 1985) (tracing the origins of the Cold War and subsequent developments in U.S. strategic thought).

16. Stephen Metz, An American Strategy for Low-Intensity Conflict, STRATEGIC REV., Fall 1989, at 9, 10-11. A study of 58 wars and major armed interventions between 1945 and 1989 found that "government composition" was the most common issue at stake for the original combatants, in contrast to earlier periods examined. HoLSTI, supra note 7, at 279. "Government composition" was defined as the imstallation or maintenance of a government regime in a country by foreign forces. Id. at 96-97. Holsti concluded that the post-World War II change whereby government composition ceased being a minor issue and became the leading issue in war and armed intervention "refiects the cold war competition between the United States and the Soviet Umion, where control over governments of client states, friends, and allies was more important as a means of conducting the competition against the opponent than control over territory and resources." Id. at 279.

17. D. Dennison Lane \& Mark Weisenbloom, Low-Intensity Conflict: In Search of a 
After the U.S. withdrawal from Southeast Asia in 1975, the revolutionary warfare and counterinsurgency tactics einployed by the United States in Vietnam were largely discredited and were abandoned by the military. ${ }^{18}$ Instead, post-Vietnam inilitary doctrine focused strictly on conventional warfighting between organized forces. ${ }^{19}$ During the 1980s, however, revolutionary and counterinsurgency doctrines began to reemerge, with renewed interest in LIC. ${ }^{20}$ In 1986, Congress, perceiving a lack of capability in the U.S. military for LIC operations, created the Special Operations Command within the Departınent of Defense, as well as the position of assistant secretary for low-intensity conflict and special operations. ${ }^{21}$

With the ehinination of a potential Soviet conventional attack, U.S. post-Cold War foreign policy appears to have shifted to the promotion of international stability and security in the "new world

Paradigm, INT'L DEF. ReV., Jan. 1, 1990, at 35.

18. Jerome W. Klingaman, U.S. Policy and Strategic Planning for Low-Intensity Conflict, in LOW-INTENSITY CONFLICT IN THE THIRD WORLD 161, 164-65 (Lewis B. Ware et al. eds., 1988). In distancing itself from the defeat in Vietnam, the U.S. military refocused its efforts towards fighting the classical, European-style war and away from the counterinsurgency mission such as that encountered in Southeast Asia. SAM C. SARKESIAN, THE NEW BATTLEFIELD 154 (1986). The counterinsurgency and unconventional warfare methods used in Vietnam, irrespective of their effectiveness, were further stigmatized by claims that the U.S. involvement in Southeast Asia was immoral and illegal.' Id. at $136-38,143-45$.

19. JENNIFER M. TAW \& ROBERT C. LEICHT, THE NEW WORLD ORDER AND ARMY DOCTRINE 21-22 (RAND Publication Series No. R-4201-A, 1992). Modern U.S. military doctrine is largely based on Clausewitzian theory, which calls for the destruction of an enemy's military forces and capabilities as the primary means of achieving political control over the enemy. See Arthur V. Grant, Strategic Decisions: The Mire of Low-Intensity Conflict, COMP. STRATEGY, Apr.-June 1991, at 165, 172; Lane \& Weisenbloom, supra note 17, at 36. For instance, until 1986, the U.S. Army's senior tactical manual on general operations, FM 100-5, did not recognize LIC as a valid doctrinal approach to certnin field situations. TAW \& LEICHT, supra, at 22. LIC as a military doctrine was largely relegated to use within the Special Operations Forces. Id. at $13,16$.

20. The Reagan admimistration recognized that LIC operations, particularly in the Third World, had the potential to affect U.S. interests adversely, even if such operations were localized and independent of the Cold War conflict, and that the Umited States needed to enhance its capabilities for dealing with such potential threats. HoLSTI, supra note 7 , at 293-94.

21. 10 U.S.C. \& 167 (1988 \& Supp. IV 1992). Although occasionally it has been thought that \& 167 was enacted as part of the Goldwater-Nichols Defense Reorganization Act of 1986, Pub. L. No. 99-433, 100 Stat. 992 (codified as amended in scattered sections of 10 U.S.C.), the provision actually was passed as part of a continuing resolution appropriations bill, Act of Oct. 30, 1986, Pub. L. No. 99-591, 100 Stat. 3341-123 (1986);

Act of Oct. 18, 1986, Pub. L. No. 99-500, 100 Stat. 1783-123 (1986). 
order.,22 The process of deindustrialization has produced a vulnerable, highly imtegrated, and interdependent global economic system that is susceptible to disruption, especially from newly industrialized and less-developed countries. ${ }^{23}$ LIC can be seen as a means for dealing with such disruptions when the "political, cultural, and economic considerations [of a given threat] are of greater miportance than purely military concerns."24

As a separate foreign policy instrument im its own right, LIC has growing acceptance, im recognition that the United States will continue to be threatened by closely related unconventional conflicts to which conventional strategies and response mechanisms would be inappropriate. ${ }^{25}$ As a doctrine, LIC recognizes that conventional military approaches have been ineffective in deterring contingency operations, msurgencies, and terrorism. ${ }^{26}$ The successful einployment of LIC will "allow highly-developed states to achieve selected objectives while reducing risks in a world where proliferation of inass destruction weapons, missile dehivery systeins,

22. TAW \& LEICHT, supra note 19, at 1; see President George H. Bush, Operation Desert Storm Is Working: Address at the Reserve Officers Association and Annual Dinner, in DEP'T ST. DISPATCH, Jan. 28, 1991, at 53 ("What . . . is . . a at stake is not simply our energy or economic security and the stability of a vital region, but the prospects for peace in the post-Cold War era-the promise of a new world order based upon the rule of law."); Remarks and a Question-and-Answer Session at a White House Briefing for Representatives of the Arab-American Cominunity, 26 WEEKLY COMP. PRES. Doc. 1432, 1432-33 (Oct. 1, 1990) (quoting President Bush):

Our action in the Gulf is about our determination to stand up with other nations against aggression, and to preserve the sovereignty of nations .... It is about our vital national security interests and ensuring peace and stability in the world. ... Our objective[] remain[s] clear: ... a new world order in which the nations of the world, East and West, North and South, can prosper and live together.

23. Robert C. Freysinger, U.S. Military and Economic Intervention in an International Context of Low-Intensity Conflict, 39 POL. STUD. 321, 331-33 (1991).

24. Id. at 322-23. Failure of the United States to maintain an effective LIC capabiity "might result in destabilized friendly governınents, . . . reduce U.S. access to crucial resources and sea lanes, deprive America of important privileges (particularly transit rights and overseas facilities), and open opportunities for opponents to exploit resultant U.S. weaknesses." READINESS SUBCOMM. OF THE HOUSE COMM. ON ARMED SERVS., 1015T CONG., 2D SESS., U.S. LOW-INTENSITY CONFLICTS 1899-1990, at 1 (Comm. Print 1990) [hereinafter CONGRESSIONAL REPORT].

25. Klingaman, supra note 18, at 165-66; see William J. Olson, Low Intensity Conflict: The Institutional Challenge, in UNCOMFORTABLE WARS, supra note 2, at 45, 54 (noting resistance by the defense establishment to fully developing the LIC mission for the military in spite of the fact that LIC is "the inost likely threat environment" that will face the United States in the future).

26. Grant, supra note 19, at 166. 
and other sophisticated devices makes mid- and high-intensity warfare increasingly unattractive to rational decisionmakers."27

The successful employment of LIC as a foreign relations instrument, however, requires strategy fundamentally different from conventional approaches. ${ }^{28}$ An approach using LIC may have advantages over conventional military tactics, particularly when used in the context of Third World conflict. Future use of conventional forces by the United States to achieve certain security and stability objectives is unlikely unless a compelling national interest, such as preserving the availability of oil, is at stake and there is international support for the use of such force. ${ }^{29}$ Further, as a result of the post-Cold War drawdown, there may not be sufficient U.S. military resources and capabilities to carry out such missions. ${ }^{30}$

The employment of LIC to achieve U.S. objectives raises constitutional questions involving the separation of powers, because the integration of both military and nonmilitary response mechamisms requires the President to exercise not only general executive power to conduct foreign relations but also potential war powers. ${ }^{31}$ Any LIC strategy by the United States would probably use psychological power, political power, economic power (including both foreign aid and sanctions), and military power. ${ }^{32}$ The exercise of such influence would translate into programs such as diplomatic initiatives, economic aid, civic action, extended military training and assistance and provision of military supplies, covert special operations, psychological warfare, and direct U.S. military inter-

27. CONGREssional REPORT, supra note 24 , at 1 . The report further notes that "LIC techniques that are cheap to employ but costly to counter also may enable weak nations and subnational groups (such as transnational terrorists, insurgents, and narcotic cartels) to compete effectively with powerful opponents ...." Id.

28. See Richard A. Shultz, The Low-Intensity Conflict Environment of the 1990s, 517 ANNALS AM. ACAD. POL. \& Soc. SCI. 120, 133 (1991). Shultz states that there are several general imperatives to which any LIC should adhere. First, political considerations should be more important than military objectives. Second, strategy must involve the joint, integrated, and coordinated use of both military and nonmilitary means. Third, LIC is viewed as a long-term policy, and hence, flexible and adaptive strategy and tactics must be employed. Fourth, LIC should be used to establish credibility and legitimacy. Id. at 125.

29. See TAW \& LEICHT, supra note 19 , at 5 .

30. Id. In addition, it has been suggested that the military's focus since Vietnam on fighting solely in mid- to high-intensity conflict has created weakness and inadequacy in the ability of the Departinent of Defense to respond to a LIC. See Bernard F. McMahon, Low-Intensity Confliet: The Pentagon's Foible, ORBIS, Winter 1990, at 3.

31. See Shultz, supra note 28, at 133.

32. Metz, supra note 16 , at 14 . 
vention. ${ }^{33}$ Because an integrated response involves both military and nonmilitary assets, a successful LIC requires an enormous amount of command and control at the highest levels of government to coordinate the various political, economic, psychological, and military aspects of the mission, which must operate together in order to bring about the desired ends. ${ }^{34}$

\section{B. General Scope of LIC Operations}

Some commentators liave argued that LIC is a form of warfare in which the ultimate goal is "the dissolution of an entire social order and the creation of a new set of social values." ${ }^{.35}$ It takes place not only at the military level, but also at the pohtical, economic, social, and psychological levels. ${ }^{36}$ As applied presently, the term LIC denotes a broad scope of potential threats and response measures that fall sliort of conflict between conventional military forces. ${ }^{37}$ LIC represents an alternative strategy to conventional warfare, one that does not treat the destruction or neutralization of the enemy's military forces as the primary objective. ${ }^{38}$

Whereas traditional warfare can be envisioned as an organized conflict between nation-states, such as the Iraq-Kuwait conflict of 1990-1991 or a liypothetical NATO-Warsaw Pact confrontation, LIC may occur in a variety of circumstances. ${ }^{39}$ Froin the U.S. perspective, LIC represents limited war and is constrained by certain restrictions. Because, when engaged in a LIC, the United States does not intend to use all necessary military ineans to prevail, defeat becoines a legitimate outcome. ${ }^{40}$ Progress in LIC be-

33. Freysinger, supra note 23 , at 323.

34. Harry G. Summers, On Joint Doctrine for Low-Intensity Conflict, in LOW-INTENSITY CONFLICT AND MODERN TECHNOLOGY 365, 375-76 (David J. Dean ed., 1986).

35. Lane \& Weisenbloom, supra note 17 , at 37.

36. Id.; see Metz, supra note 16 , at 14 .

37. The mearing of LIC has differed according to the context in which it is used; it can refer to a specific environment itself, conflicts within a specific environment, categories of operations within a specific environunent, insurgency or counterinsurgency operations in general, all special operations, or even all U.S. operations in the Third World. TAW \& LEICHT, supra note 19, at 17; see Sam C. Sarkesian, Low-Intensity Conflict: Concepts, Principles, and Policy Guidelines, in LOW-INTENSITY CONFLICT AND MODERN TECHNOLOGY, supra note 34 , at $9,12-13$.

38. Lane \& Weisenblooin, supra note 17 , at 37.

39. See CONGRESSIONAL REPORT, supra note 24 , at 13-27.

40. Grant, supra note 19, at 167. Defeat is not an outcome to be avoided at all costs in LIC, simce by its very nature, LIC is intended to be limited. Defeat implies only that the United States does not intend to exercise the necessary military means to ac- 
comes difficult to measure in traditional military terms, such as the amount of territory held or the number of enemy personnel killed. Furthermore, tactical or operational victories on the battlefield do not necessarily preordain a successful outcome in the LIC itself. ${ }^{41}$

The 1990 version of the National Security Strategy of the Umited States placed LIC "at the lower end of the conflict spectrum," noting that it "involves the struggle of competing principles and ideologies below the level of conventional war." Chiefs of Staff have defined LIC on the operational continuum as "[p]ohitico-military confrontation between contending states or groups below conventional war and above the routine, peaceful competition among states.... [LIC] is waged by ... political, economic, imformational, and military instruments." ${ }^{33}$ The Joint Chiefs of Staff also noted that while LIC operations are "often localized, generally in the Third World, [they] contain regional and global security imphications." 44

The boundaries of LIC have not been precisely defined. ${ }^{45}$ At times the term LIC appears to be a catchall for various operations, including those in which no military mvolvement is required. ${ }^{46} \mathrm{At}$

complish its political objectives. There are often good reasons, such as the potential for the use of nuclear weapons or the expansion of the conflict to involve third-party countries, that the United States chooses not to escalate a confrontation.

Defeat in conflict, however, is not an outcome readily accepted by the U.S. public. The absence of a complete and total victory in mid-intensity conflicts such as those in Korea, Vietnam, and Iraq, notwithstanding the fact that the U.S. military forces were operating under restricted authority, has greatly affected the public's perceptions regarding the commitment of U.S. military forces to conflicts abroad. In Iraq, for instance, the failure of the United States to oust Saddam Hussein from power left the feeling of an incomplete victory. However, the U.N. authorization under which U.S. forces were operating extended only to the removal of Iraqi forces occupying Kuwait. See SCOR Res. 678, U.N. SCOR, 45th Sess., U.N. Doc. S/RES/678 (1990).

41. See Grant, supra note 19 , at 168-69.

42. The White House, National Security Strategy of tHe UNITEd STates 28 (1990); see CONGRESSIONAL REPORT, supra note 24 , at 3 . The report added that LIC actions "occupy the imprecise space between normal peacetime competition and combat equivalent to that in Korea and Vietnam." Id. at 1.

43. Grant, supra note 19, at 166 (quoting JonT ChIEFS OF STAFr, JCS PUblication $1-01$, at $214(1989))$.

44. Id.

45. Klingaman, supra note 18 , at 162-64. A congressional report found several fundamental patterns associated with modern LIC: extreme diversification, cultural shock, fixation on armed force, concentration on communism, preeminence of manpower, unique deterrent techniques, low utility of nultilateral alliances, and public opinion misconceptions. CONGRESSIONAL REPORT, supra note 24 , at 75.

46. See Summers, supra note 34 , at $365,365-66$. Sumimers finds that grouping a wide variety of missions within the label "LIC" makes the term "inherently misleading" and 
the lower levels of LIC, military force can range from "subtle but coercive military maneuvers and displays to more potent signaling devices such as warnings, alerts, call-ups, and demonstrations of force." ${ }^{47}$ The use of force within the context of LIC could escalate to surgical strikes, reprisals, limited but overt interventions, and limited conventional wars. ${ }^{48}$ Types of situations characterized as LIC include insurgency and counterinsurgency, peacetime contingency operations, counterterrorism, counternarcotics operations, and peacekeeping. ${ }^{49}$ Nevertheless, each specific type of mission differs considerably in terms of strategic and tactical considerations as well as in terms of the military and civihan components involved. ${ }^{50}$

LIC also has been described as "military operations other than war" (MOOTW), "military operations short of war" (MOSW), and "noncoinbat operations" (NCO) mvolving military uurits. $^{51}$ It has been suggested that if LIC covers all uses of force other than sustained warfare between conventional forces, then LIC should also include attempted coups, kidnapping, civil disorders, assassinations, and armed expropriation..$^{52}$ It should be noted, however, that the designation of a given conflict as "low-mtensity" is a relative term: while a LIC may be minor to a superpow-

thus confuses the dividing line between war and peace. Id. at 365 . Summers notes that the public is aware that

[t]here is a fundamental difference . . . between American "peacetime" support for allies threatened with terrorism, crises, revolutions, and counterrevolutions which do not require the commitment of American combat forces on the one hand; and the direct commitment of U.S. combat forces under presidential authority ... or congressional authority on the other.

Id. The term is also unclear as to the appropriate measure of intensity, "whether it is in terms of lethality, technology, numbers of American forces involved, or some other [factor] . . . ." TAW \& LEICHT, supra note 19, at 19.

47. HoLSTI, supra note 7 , at 272.

48. Id.

49. Freysinger, supra note 23, at 324 ; see CONGRESSIONAL REPORT, supra note 24 , at 5; Lane \& Weisenbloom, supra note 17 , at 37.

50. SARKESIAN, supra note 18 , at 133 . Thus, it has been observed that "the categories themselves serve no useful purpose; they span non-combat to combat operations and have little in common that would logically suggest their relationship within the LIC rubric." TAW \& LEICHT, supra note 19, at 18.

51. TAW \& LEICHT, supra note 19 , at $6-8$.

52. Klingaman, supra note 18 , at 166 . Examining the national security threats that are dealt with primarily by civilian authorities, Klingaman further adds "coercive diplomacy, disinformation, subversion, illegal drug traffic, extortion, blackınail, and the precipitous curtailment of strategic resources" as categories of LIC. Id. 
er such as the United States, it can be "total war" to the opposing side. $^{53}$

\section{Determining LIC's Upper Threshold for the Purposes of Con- stitutional Analysis}

At some point along the conflict spectrum envisioned by military and national security strategists, a LIC becomes a mid-intensity conflict. ${ }^{54}$ Presumably, at this point, congressional authorization would be required for military action, provided that the conflict does not involve a direct attack agamst U.S. territory or U.S. military forces stationed abroad, because the conflict would be considered a "war" under Article I of the Constitution. 55 . Thus, conflicts such as those in Korea, Vietnam, or Iraq-Kuwait would require congressional approval prior to the commitment of U.S. military forces. On the other hand, military operations that fall below this point would be considered LIC, and under a theory of presidential prerogative, would not be subject to such a constitutional restriction in the absence of specific legislation.

Despite the lack of precise limits defiming the scope of LIC, there is a sufficient franework to enable constitutional analysis of presidential authority to conduct military operations in LIC. First, it is clear that combat operations approaching the scale of World War II or the conflicts in Korea and Vietnam would lift a conflict beyond the level of LIC. Thus, one could use a precedent-based approach in determining whether a military deployinent into a conflict area would extend beyond the authority conferred by presidential prerogative in the context of LIC. For example, in Dellums v. Bush, the plaintiffs alleged that the President had deployed 230,000 U.S. troops to the Persian Gulf region and had planned, pursuant to U.N. authorization, to launch an offensive military action against Iraqi forces. ${ }^{56}$ The U.S. district court, rul-

53. Lane \& Weisenbloom, supra note 17 , at 37 ; Metz, supra note 16 , at 11 . The term "LIC" also does not imply that the United States will face opponents armed only with low-quality and inferior weapons. See U.S. GENERAL ACCOUNTING OFFICE, U.S. WEAPONS-THE LOW-INTENSITY THREAT IS NOT NECESSARILY A LOW-TECHNOLOGY THREAT 3 (1990).

54. See supra notes $42-43$ and accompanying text.

55. See supra note 6.

56. 752 F. Supp. 1141, 1146 (D.D.C. 1990). While the district court rejected the President's argument that the issue was a political question, the court ultimately dismissed the plaintiffs' action on the grounds of ripeness. Id. at 1146, 1152. 
ing on the issue of whether the case was a political question, found that "the forces involved are of such magnitude and significance as to present no serious claim that a war would not ensue if they became engaged in combat;" tion in concluding that an offensive entry imto Iraq by several hundred thousand United States servicemen under [such] conditions ... could be described as a 'war' within the meaning of Article I, Section 8, Clause 11, of the Constitution."

Second, if it is unclear whether a possible military operation falls into the category of LIC, one could also apply a combination of precedent and factor analysis. Precedent analysis would compare the operation to past military actions considered to be LIC. $^{59}$ Factor analysis would consider a number of military circumstances that might give some indication of whether the proposed action would be a LIC, such as the number of U.S. forces to be deployed; the amount of U.S. firepower to be used; the projected time the operation would take to complete; the strategic and tactical military objectives; the projected strength, firepower, and sophistication level of enemy forces; the probability that U.S. intervention would cause subsequent third-party intervention; the risk of escalation to conventional or nuclear combat; the projected number of U.S. casualties; and whether an exit strategy has been developed and clarified. Consideration of both precedent and factor analysis, while not a bright-line test, should offer sufficient gnidance in determining when an action is a LIC.

\section{CONSTITUTIONAL POWERS AND LOW-INTENSITY CONFLICT}

In his Second Treatise of Government, John Locke described three forms of power found im government: legislative, executive, and federative. ${ }^{60}$ While noting that the legislative and executive

57. Id. at 1145 .

58. Id. at 1146 .

59. See examples listed supra note 4 and text accompanying note 33 .

60. John Locke, Two Treatises of Government: The Second Treatise-An Essay Concerning the True Origin, Extent and End, of Civil Government, in Classics IN POLITICAL PHILOSOPHY 284, 316-17 (Jene M. Porter ed., 1989). Locke defined legislative power as "that which has a right to direct how the force of the commonwealth shall be employed for preserving the community and the members of it." Id. at 316. Executive power, on the other hand, "slould see to the execution of the laws that are made, and remain in force." Id. Locke noted that the federative power derived from the status of society as a community and "therefore contains the power of war and peace, leagues and alliances, 
powers should be contained in separate entities, he stated otherwise with respect to the federative and executive powers: "Though ... . distinct in themselves, ... . they are hardly to be separated, and placed ... in the hands of distimct persons." Locke concluded that if different persons who could act independently of each other were to hold separately the executive and federative powers, this "would be apt sometime or other to cause disorder and ruin." 62

The Framers of the Constitution, however, divided the power to engage in war between the President and Congress. Unhike the British system, in which the war power was be vested with the sovereign, ${ }^{63}$ the Framers placed the authority to declare war with Congress so as, in the words of Thomas Jefferson, to form "one effectual check to the Dog of war." ${ }^{164}$ At the same time, the President was given full command and control over the armed forces. ${ }^{65}$ The allocation of authority regarding the use of military force between the two branches has created constitutional problems regarding the authority to use force, especially in LIC situations.

\section{A. Interpreting the Foreign Affairs Power Within the Context of Low-Intensity Conflict}

Under the U.S. Constitution, the foreign affairs power is considered national in nature and is shared between the executive and the legislature. ${ }^{66}$ Hence, the Suprene Court has recognized im-

and all the transactions, with all persons and communities without the commonwealth." Id. at 316-17.

61. Id. at 317.

62. Id. Locke noted that the measures to be used by the executive and federative powers were quite similar and that they differed primarily in their overall goals, "one comprehending the execution of the municipal laws of the society within itself, upon all that are parts of it; the other the management of the security and interest of the public ...." Id.

63. See Louis Fisher, Historical Survey of the War Powers and the Use of Force, in THE U.S. CONSTITUTION AND THE POWER TO GO TO WAR 11, 12-13 (Gary M. Stern \& Morton H. Halperin eds., 1994); see also THE FEDERALIST No. 69, at 352-55, 357 (Alexander Hamilton) (Max Beloff ed., 1987) (comparing the authority of the British monarchy with the comparatively inferior powers of the U.S. presidency).

64. Letter from Thomas Jefferson to James Madison (Sept. 6, 1789), in 15 THE PAPERS OF ThOMAS JEFFerson 392, 397 (Julian P. Boyd ed., 1951).

65. U.S. CONST. art. II, § 2.

66. Compare id. cl. 1 (conferring on the President power as Commander in Chief) and id. $\S 3$ (providing that President shall receive foreign ambassadors and ministers) 
phicit constitutional authority in Congress to regulate foreign affairs, because that power is indispensable to the ability of the Urited States to function as a sovereign nation in the world. ${ }^{67}$ Likewise, the Court has also noted the importance of the President's role in foreign affairs. ${ }^{68}$

The authority to conduct LIC operations involving U.S. inilitary forces inay potentially fall within several different provisions of the Constitution. Article I grants to Congress the power to declare war and to issue letters of inarque and reprisal. ${ }^{69}$ Article II naines the President as Commander in Chief and gives him a general grant of executive power; several provisions in the Article create the power to conduct foreign relations. ${ }^{70}$ Although there are other constitutional provisions that may impact more generally on the inilitary and the ability to conduct LIC, especially within Article I, these provisions are not relevant to the issue of whether, based on the President's own Article II authority, the President is authorized to deploy U.S. military forces in a LIC. ${ }^{71}$

with id. art. I, $\S 8$, cls. 3-4, 10 (conferring on Congress the power to regulate foreign trade, establish naturalization rules, and define and punish piracy) and id. cls. 1, 11-16 (concerning Congress's power relating to the military); see also id. $\S 10$ (generally prohibiting states from engaging in foreign relations); id. art. II, $\S 2, \mathrm{cl} .2$ (conferring on the President the power to make treaties and appoint anbassadors, subject to Senate approval).

67. Perez v. Brownell, 356 U.S. 44, 57 (1958); see also United States v. CurtissWright Export Corp., 299 U.S. 304, 318 (1936) ("[T]he investment of the federal governinent with the powers of external sovereignty did not depend upon the affirmative grants of the Constitution.").

68. Justice Sutherland stated in Curtiss-Wright that "[i]n this vast external realm [of external affairs], with its important, complicated, delicate and manifold problems, the President alone has the power to speak or listen as a representative of the nation." 299 U.S. at 319.

69. U.S. CONST. art. I, § 8, cl. 11.

70. Id. art. II, $\S \S 1-2$.

71. For instance, Article I gives Congress the power "[t]o raise and support Armies" and "[t]o provide and maintain a Navy." Id. art. I, $\S 8$, cls. 12, 13. Clearly, Congress has the power to disband the military and thereby eliminate any LIC capability within the military. However, this scenario is extremely unlikely and in fact can be refuted by the negative implication of legislation passed by Congress in 1986 requiring the executive branch to enliance the LIC capabilities of the United States. See supra note 21 and accompanying text; see also Richard H. Shultz, Jr., Covert Action, in INTELligence REQUIREMENTS FOR THE 1990S 165, 194-95 (Roy Godson ed., 1989):

Recent congressional legislation ... calls for the establislıment of a board for low-intensity conflict at the National Security Council level. The purpose of the board is to plan and coordinate the LIC policy of the United States. This creates a single channel for integrating those bureaucratic elements involved in LIC policy and plans. 
The notion of a balance between the President and Congress in the field of foreign affairs is best exemplified by Justice Jackson's concurrence in Youngstown Sheet \& Tube Co. v. Saw$y e .^{72}$ Behieving that presidential powers "fluctuate" depending on the actions taken by Congress, Justice Jackson developed a threepart analysis of executive authority. ${ }^{73}$ First, when the President acts pursuant to express or implied congressional authorization, his power is "at its maximum." " Second, when the President acts in an area of coextensive power shared with Congress but in the absence of any legislative action, he acts in a "zone of twilight" that may invite the exercise of "independent presidential responsibility."75 Third, if the President acts in contravention of expressed or implied congressional will, then his power is "at its lowest ebb," and the President inay rely only on his Article II authority independent of Congress. ${ }^{76}$

Since a confrontation predicated in LIC often mitially occurs at the political and psychological stages, ${ }^{77}$ the President is the principal policynaker, due to his executive power ${ }^{78}$ and role as chief representative of the country in foreign affairs. ${ }^{79}$ However, since engageinent in LIC often requires the use of economic assistance (e.g., foreign security assistance to a "friendly" government to use against insurgents) or military forces (e.g., counterinsurgency advisors), congressional authority is implicated. Thus, congressional involvement would be justified due to Congress's appropriations $^{80}$ and war powers. ${ }^{81}$

72. 343 U.S. 579, 634 (1952) (Jackson, J., concurring). At the time, the United States had been engaged in sustained combat operations with Communist forces on the Korean peninsula since 1950. In 1952, a possible strike by steelworkers threatened to halt U.S. production of steel, a vital supply component required by the conflict. In response, President Truman issued an executive order, without statutory authority, directing the Secretary of Commerce to seize and operate most of the nation's steel mills. Id. at 582-83. President Truman cited his general executive power under Article II and his authority as Commander in Chief of the military as justifications. Id. at 582-84.

73. Id. at 635-38 (Jackson, J., concurring).

74. Id. at 635. Under such circumstances, the President is said to "personify the federal sovereignty," id. at 636, because his power encompasses, in addition to his inherent constitutional authority, all power delegated by Congress, $i d$. at 635 .

75. Id. at 637.

76. Id.

77. See Lane \& Weisenbloom, supra note 17 , at 37 ; Metz, supra note 16 , at 14.

78. See U.S. ConST. art. II, § 1, cl. 1 .

79. See United States v. Curtiss-Wright Export Corp., 299 U.S. 304, 319-22 (1936).

80. U.S. CONST. art I, \& 9, cl. 7.

81. Id. \& 8, cls. $11-16$. 
1. Basis for Substantial Congressional Authority over LIC. During the post-World War II era, especially since the U.S. involvement in Vietnam, the extent and authority of congressional war powers have been subject to much discussion. At the Constitutional Convention, however, the War Declaration Clause was the subject of relatively brief consideration. ${ }^{82}$ While it is clear that the Framers sought to limit the ability of the President to engage in war, ${ }^{83}$ they also strove to give the President the authority to respond defensively to sudden attacks. ${ }^{84}$ To resolve such concerns, Jaines Madison successfully introduced an amendment to the original draft of the Constitution altering congressional power from that to "make" war to that to "declare" war. ${ }^{85}$ This change, however, would not authorize the President to commence an offensive war.

The provision on letters of marque and reprisal was similarly inserted into the Constitution with hittle debate or discussion. ${ }^{86}$

82. 2 James Madison, Debates in the Federal Convention of 1787, at 418-19 (Gaillard Hunt \& James B. Scott eds., 1987) [hereinafter DEBATES].

83. For instance, one delegate, George Mason, was opposed to delegating the war power solely to the President and favored a constitutional structure "clogging rather than facilitating war." 2 id. at 419.

84. The Framers overwhelmingly supported the principle that the President was not allowed to declare war in the absence of a sudden attack. For instance, when the delegates were debating whether the war powers should be exercised by both houses of Congress or just by the Senate, based on efficiency of decisionmaking, Pierce Butler suggested that the most efficient method would be to grant the war powers to the President. Id. at 418. Elbridge Gerry tersely responded that he "never expected to hear in a republic a motion to empower the Executive alone to declare war." 2 id. at 419.

85. 2 id. at 419. Another delegate, Robert Sherman, opposed the amendment on the grounds that it would augment the President's power to conduct war. Sherman argued that the President already had inherent authority to defend the country against invasion. 2 id. at $418-19$.

86. See, e.g., Jules Lobel, Covert War and Congressional Authority: Hidden War and Forgotten Power, 134 U. PA. L. REv. 1035, 1062 (1986) (reviewing the history and present applicability of the Marque and Reprisal Clause, U.S. CONST. art. I, § 8, cl. 11). Lobel notes that historically, there were technical meanings for a letter of marque and reprisal, which represented a government license for the private use of force:

A letter of marque originally authorized the crossing of borders to obtain redress, while a letter of reprisal sanctioned the use of force to secure compensation for an unlawful taking of property or goods. When issued in tandem, letters of marque and reprisal authorized injured parties to seize property, or, in extraordinary cases, foreign citizens who had refused to provide redress for an injury they had inflicted.

Id. at 1042-43 (footnotes omitted). However, during the 16th and 17th centuries, the use of letters of marque and reprisal changed from an authorization to respond to a specific instance into a more general authorization to engage in limited warfare with a foreign na- 
On the day after the Framers adopted the "declare War" language, they considered and adopted an amendment submitted by Elbridge Gerry that proposed to give Congress the power to issue letters of marque and reprisal, as the original draft of the Constitution had omitted any reference to such imstruments. ${ }^{87}$ However, Gerry "thought [that such authority was] not included in the power of war" and that letters of marque and reprisal should be included in the Constitution. ${ }^{88}$ Despite the lack of substantive debate about the clause at the Constitutional Convention, one cominentator has argued that the Framers intended to use "Letters of Marque and Reprisal" to refer to the general use of any armed hostilities short of war rather than to their inore restricted and technical definitions. ${ }^{89}$ Thus, soine have maintained that between the War Declaration Clause and the Marque and Reprisal Clause, Congress has exclusive authority regarding any use of force, including military deployments in LIC. ${ }^{90}$ This claim is further buttressed by the placement of key provisions relating to the military, or "auxiliary war powers," in Article I.

In the years from 1798 to 1800 , the United States engaged in an undeclared naval war with France that could be considered the

tion. Id. at 1043-44.

87. Id. at 1060 .

88. 2 DEBATES, supra note 82 , at 421.

89. Lobel, supra note 86 , at $1045-47$. Lobel argues,

In eighteenth century America, the term "letters of marque and reprisal" lost much of its technical meaning and came to signify any intermediate or lowintensity hostility short of declared war that utilized public or private forces, although the emphasis on the use of private forces remained. The term was used interchangeably with the terms reprisal, privateer, and commission, each of which had a somewhat different technical meaning.

When the Franers of the Articles of Confederation and the Constitution spoke of the power to issue letters of marque and reprisal, they referred to the power to authorize a broad spectrun of armed hostilities short of war. . . . More generally, many statesmen of the period used marque and reprisal to refer to a state of "imperfect war," by which they ineant any state of armed hostilities that did not rise to the level of delared [sic] war. Since the Framers and other early statesmen did not adhere to the technical definition of such letters when they discussed them in the early years of the republic, it can be argued that in general, uses of force short of war ... come[] within the sphere of the Framers' concern.

Id. (footnotes omitted); see also Review of the War Powers Resolution: Hearings Before the Investigations Subcomm. of the House Comm. on Armed Servs., 101st Cong., 1st \& 2d Sess. 290-91 (1991) [hereinafter Congressional Hearings] (statement of Morton Halperin, director, Washington, D.C., office, American Civil Liberties Union) (testifying that all uses of the military for operations short of war require prior congressional authorization under the Marque and Reprisal Clause).

90. See infra notes $109-11$ and accompanying text. 
historical equivalent of a modern LIC. The Supreme Court's decisions in Bas v. Tingy ${ }^{91}$ and Little v. Barreme, ${ }^{92}$ cases that resulted from incidents during this period, laid the primary legal foundation for the assertion of congressional supremacy in the context of LIC. The fact that they were decided less than fifteen years after the ratification of the Constitution implies that they represent an accurate reflection of the original intent of the Franers' separation of powers doctrine regarding foreign and military affairs.

In Bas, the issue concerned whether the United States was in a state of hostihities with France, despite the absence of a declaration of war. ${ }^{93}$ The Supreme Court concluded that there were two types of war, "perfect" and "imperfect," and that Congress was entitled to authorize both under its war powers. ${ }^{94}$ Hence, Bas, by implication, could be interpreted to support the principle of congressional supremacy im the area of LIC, at least when any military force is used. ${ }^{95}$

Four years later, the decision in Bas was reinforced by the Suprenie Court's holding in Barreme. The Barreme decision involved the President's implementation of a non-intercourse statute enacted by Congress authorizing the interception of vessels headed to French ports. ${ }^{96}$ The Suprenie Court ruled that the seizure of a

91. 4 U.S. (4 Dall.) 37 (1800).

92. 6 U.S. (2 Cranch) 169 (1804).

93. Bas, 4 U.S. at 37.

94. The Court's decision was delivered seriatim. Justice Washington stated that whenever the use of force was sanctioned by the governments in external affairs, a state of "public war" existed, which could then be subdivided into two separate categories. Id. at 40-41. "Perfect" or "solemn" war existed after a formal declaration "because one whole nation is at war with another whole nation; and all the members of the nation declaring war, are authorized to commit hostilities against all the members of the other, in every place, and under every circumstance." Id. at 40. "Imperfect" war, on the other hand, was "more confined in its nature and extent; being limited as to places, persons, and things . . . because those who are authorized to commit hostilities, act under special authority, and can go no farther." Id. Similarly, Justice Chase noted that "congress is empowered to declare a general war, or congress may wage a limited war." Id. at 43 .

95. For instance, Justice Paterson concluded that "[a]s far as congress tolerated and authorized the war on our part, so far may we proceed in hostile operations." Id. at 45 . Justice Chase observed that "if a partial [or limited] war is waged, its extent and operation depend on our municipal laws." Id. at 43.

96. Barreme, 6 U.S. at 177. The Act of February 9, 1799, "An act further to suspend the commercial intercourse between the United States and France, and the dependencies thereof," ch. 2, 1 Stat. 613, prohibited any U.S. vessel from engaging in any travel or commerce within French-controlled territory, and its enforcement provision authorized the seizure of any ship caught violating the prohibition. Id. 
suspected vessel was unlawful because the presidential order under which it was carried out went beyond the actions authorized by Congress. $^{97}$ Thus, Barreme reaffirmed the idea that any hostile action, even in an "imperfect" war, had to be authorized by Congress. However, the Barreme Court, interestingly, did not discuss the use of "inherent" presidential powers to alter or implement the non-intercourse statute.

In many of the LIC operations in which the United States has engaged, Congress has asserted its power to authorize the actions, and the executive branch has on occasion recognized such congressional authority. ${ }^{98}$ For imstance, in 1801, President Jefferson dispatched a U.S. Navy task force to the Mediterranean Sea to protect U.S. merchant ships and citizens who were under threat by the Barbary pirates of Tripoh if payment of tribute was not made. ${ }^{99}$ In requesting legislation to authorize a military response, President Jefferson stated that U.S. forces would be "[u]nauthorized by the Constitution, without the sanction of Congress, to go beyond the line of defense ...."100 Further, in 1846, President

97. Barreme, 6 U.S. at 177-78. Because the seized vessel, the Flying Fish, was on a voyage from a French port, rather than sailing to a French port, the U.S. commander's actions exceeded his authorization from Congress. As Chief Justice Marshall noted, "[I]f only vessels sailing to a French port could be seized on the high seas, the law would be very often evaded ...." Id. at 178. Thus, the order issued by the President, which allowed the seizure of any vessel headed to or from a French port, was "a construction much better calculated to give [the act] effect." Id. Nevertheless, because the order authorized broader action than permitted by the congressional statute, it was unlawful. Id. at 179.

98. See ANn VAN Wynen Thomas \& A.J. Thomas, JR., The WaR-Making PowERS OF THE PRESIDENT 31-35 (1982).

99. See Fisher, supra note 63, at 17; Lobel, supra note 86 , at 1105-06. In fact, the Tripoli government had already issued a "declaration of war" against the United States. Id.

In the 1980s, the modern state of Libya made similar threats against ships of the United States and other nations by claiming the entire Gulf of Sidra in the Mediterranean Sea as its territorial waters, in contravention of the internationally recognized 12 mile limit. See CASPAR W. WeInBerger, FIGHTING FOR PEACE 175-78 (1990). In response to that claim, the United States has routinely engaged, based only on presidential authority, in "freedom of navigation" exercises by the Navy within the disputed waters, usually involving a carrier battle group. Id. at 176 . On one occasion, in 1981, such exercises provoked a Libyan response, as two SU-22 fighters opened fire with air-to-air missiles against two U.S. Navy F-14 Tomcat fighters. Id. at 177. The F-14s, after avoiding the Libyan missiles and acting in self-defense, shot down both Libyan fighters. Id. A similar incident also occurred in 1989. See supra note 4.

100. Thonias Jefferson, First Annual Message, in 1 A COMPILATION OF THE MEsSAGES AND PAPERS OF THE PRESIDENTS 1789-1897, at 326, 327 (James D. Richardson ed., 1897). However, sonie contemporary commentators have debated whether President 
Polk dispatched U.S. troops to occupy disputed territory on the Texas-Mexico border without congressional authorization, an action that subsequently provoked hostilities between U.S. and Mexican forces and was a precursor to the Mexican-American War. ${ }^{101} \mathrm{Al}$ though Congress eventually enacted a formal declaration of war pursuant to the Constitution, the House of Representatives issued a resolution that censured President Polk's deployment of military forces. ${ }^{102}$ Thus, it lias been argued that despite other past examples of unilateral deployment of military forces by the President, there are "in any event ... historical precedents and practices which recognize limits upon presidential power in favor of Congress." 103

Since World War II, moreover, Congress has attempted to reassert authority over the deployinent of U.S. armed forces abroad. ${ }^{104}$ Most significantly, Congress has souglit to restrain the President's ability to deploy military forces in potentially hostile situations by enacting the War Powers Resolution. ${ }^{105}$ In the courts, this authority has been claimed unsuccessfully by certain

Jefferson's acknowledgment of congressional authority was actually made in good faith or was a mere political statement designed to induce congressional approval for offensive operations. ABRAHAM D. SOFAER, WAR, FOREIGN AFFAIRS AND CONSTITUTIONAL POWER 212-14 (1976).

101. Fisher, supra note 63 , at 18.

102. Id.

103. THOMAS \& THOMAS, supra note 98 , at 35 .

104. Congressional Hearings, supra note 89, at 133 (statement of Eugene V. Rostow, Distinguished Visiting Professor of Law and Diplomacy, National Defense University). Rostow stated that

we should look at the War Powers legislation not of itself, but as part of a much larger congressional effort extending over a period of 50 years or so, to take over a good many of the President's executive powers, especially in the Id. field of foreign affairs and the war power ....

105. 50 U.S.C. $\$ \S 1541-1548$ (1988 \& Supp. V 1993); see also infra notes 174-80 and accompanying text. Some have criticized the War Powers Resolution as making congressional war powers subservient to presidential authority. See THOMAS F. EAGLETON, WAR AND PREsidential POWER: A Chronicle of CONGREssional SuRRENDER 203-05 (1974) ("By failing to define the President's powers in legally binding language, the bill provided a legal basis for the President's broad claims of inherent power to initiate war. ... [Thus, r]ather than tying the President's hands ... the bill would tie Congress' hands.").

It has also been argued that portions of the War Powers Resolution are an unconstitutional infringement on presidential authority. See ROBERT F. TURNER, REPEALING THE WAR POWERS RESOlution: RESTORING THE RULE OF LAW IN U.S. FOREIGN POLICY 109-21 (1991); see also Richard M. Nixon, Veto of the War Powers Resolution, PUB. PAPERS 893, 893-95 (Oct. 24, 1973). 
members of Congress to extend to LIC operations involving U.S. military forces. ${ }^{106}$ Subsection 2(a) of the Resolution observes that the introduction of military forces into hostilities or imminent involvement in hostilities involves the "collective judgment of both the Congress and the President," which was the intent of the Constitution's Framers. ${ }^{107}$ Subsection 2(c) states that the President may not commit military forces into "hostilities, or into situations where imminent involvement im hostilities is clearly indicated by the circumstances," except pursuant to a congressional "declaration of war, specific statutory authorization, or a national emergency created by attack upon the United States, its possessions or territories or its armed forces." ${ }^{103}$ The War Powers Resolution, criticism notwithstanding, represents the constitutional viewpoint of strictly interpreting the war powers to reside within the domain of Congress.

Hence, the congressional supremacy argument holds that the Constitution requires Congress to grant explicit advance authorization to the President before permitting the use of force at any level of conflict, including that considered low-intensity. ${ }^{109}$ Sup-

106. See, e.g., Conyers v. Reagan, 765 F.2d 1124 (D.C. Cir. 1985) (challenging the invasion of Grenada); Lowrey v. Reagan, 676 F. Supp. 333 (D.D.C. 1987) (involving the question of whether the escort of Kuwaiti tankers in the Persian Gulf triggered reporting requirement of $\S 4(\mathrm{a})(1)$ of War Powers Resolution, 50 U.S.C. $\S 1543(\mathrm{a})(1)$ (1988)); Sanchez-Espinoza v. Reagan, 568 F. Supp. 596 (D.D.C. 1983) (challenging Department of Defense support of insurgency in Nicaragua), aff'd on other grounds, 770 F.2d 202 (D.C. Cir. 1985); Crockett v. Reagan, 558 F. Supp. 893 (D.D.C. 1982) (challenging the President's deployment of U.S. military advisors to El Salvador), aff'd, 720 F.2d 1355 (D.C. Cir. 1983), cert. denied, 467 U.S. 1251 (1984).

107. 50 U.S.C. § 1541(a) (1988), amended by Pub. L. No. 103-423, 108 Stat. 4358 (1994). However, most supporters of congressional supremacy acknowledge that $\S 2$ is not binding on the President and represents only a nonexhaustive list of presidential authority. See, e.g., Cyrus R. Vance, Striking the Balance: Congress and the President Under the War Powers Resolution, 133 U. PA. L. REv. 79, 81 (1984). Thus, the most controversial portions of the War Powers Resolution are the reporting and deadline provisions found in \$ 4. 50 U.S.C. \& 1543 (1988); see infra note 175.

108. 50 U.S.C. $\$ 1541$ (c).

109. See, e.g., JOHN HART ELY, WAR AND RESPONSIBILITY 126 (1993); Morton H. Halperin, The Way to Pick a Fight: Democratizing the Debate on Using Force Abroad, WASH. POST, Jan. 10, 1993, at C1; William Van Alstyne, Additional Written Comment by William Van Alstyne: In a Republic and Under a Constitution Such as Ours, It Is for Congress to Say How the Armed Forces Shall Be Used, 43 U. MIAMI L. REv. 47, 53 (1988).

In testifying before a House Armed Services subcommittee, Morton Halperin, thendirector of the Washington, D.C., office of the American Civil Liberties Union, perhaps best summarized the position of those who favor exclusive congressional authority over LIC: 
port of congressional superiority is based on alternative rationales that are not mutually exclusive. One argument is that involvement in LIC constitutes an exercise of the War Declaration Clause, by which Congress retains the original authority to linit the President's ability to deploy military forces, notwithstanding the historical encroachment by the President on such authority. ${ }^{110} \mathrm{Al}-$ ternatively, even if LIC does not fall within the War Declaration Clause, it is the contemporary equivalent of a letter of inarque and reprisal, which Congress has the exclusive authority to issue. ${ }^{111}$

\section{Constitutional Arguments for Presidential Prerogative in the} Context of LIC. The Commander in Chief Clause was approved by the Constitutional Convention without any debate on the record. ${ }^{112}$ A substitute provision that had earlier been defeated

I think Congress should make it clear that any American intervention in a military conflict-whether it's by sending forces as a deterrent, by sending forces into combat, or paramilitary operation, or sending large amounts of weapons to an ongoing conflict-that any one of those should require, not only consultation with the Congress, but advance authorization by Congress in the form of legislation, whether it takes the old-fashioned kind of a declaration of war or some other kind of resolution, Congress should clearly be authorizing the President to engage in the military operation.

That decision ought to precede intervention except in the few narrow circumstances where I think the President does have the authority to act without that kind of consultation, and that is to defend American forces abroad, to rescue Americans, and to defend the United States from a direct attack. be required.

But in all other situations, I would say that advance authorization should Congressional Hearings, supra note 89, at 15-16.

Interestingly, Halperin was subsequently nominated in 1993 by President Clinton as Assistant Secretary of Defense for Democracy and Peacekeeping. However, in tight of significant political opposition to his confirmation by certain senators, in part due to his views regarding authority to use force, Halperin withdrew his nomination in January 1994. Thomas W. Lippman, Halperin Says No to Renomination for Defense Post, WASH. POST, Jan. 11, 1994, at A17; Eric Schmitt, Pentagon Nominee Withdraws Name, N.Y. TrMES, Jan. 10, 1994, at A1.

110. Fisher, supra note 63, at 11 .

111. Congressional Hearings, supra note 89, at 14-16; ELY, supra note 109, at 3 n.3; Lobel, supra note 86, at 1046-47; Peter Raven-Hansen, Constitutional Constraints: The War Clause, in THE U.S. CONSTITUTION AND THE POWER TO GO TO WAR, supra note 63 , at 29, 30-31; see supra note 89.

112. David L. Hall, The Reagan Wars: a Constitutional Perspective on WAR POWERS AND THE PRESIDENCY 17 (1991); see Michael J. Glennon \& Allison R. Hayward, Collective Security and the Constitution: Can the Commander in Chief Power Be Delegated to the United Nations?, 82 GEO. L.J. 1573, 1587-93 (1994) (presenting historical overview of development of the "Commander in Chief clause"). 
would have instead given the President the "power to direct (agreeable to law) the operations" of the military. ${ }^{113}$ Thus, the Framers clearly intended to name the President, a civilian, as the military commander of all U.S. armed forces. In other words, the Commander in Chief Clause would inake the President the "first general and admiral" of the nation, which would perınit "nothing inore than the supreme command and direction of the military and naval forces."114

Although the presidential powers explicitly granted by the Constitution are not as elaborately identified as those given to Congress, the President nevertheless maintains significant inherent constitutional authority to conduct foreign relations. In addition to the power to act as Commander in Chief of the inilitary, Article II gives the President the exclusive power to make treaties, appoint ambassadors, and receive foreign ambassadors and ministers. ${ }^{115}$ Presidential authority may also be implied in the President's oath of office. ${ }^{116}$ In addition, the President clearly holds all executive power of the federal government ${ }^{117}$ and has a duty to execute the law faithfully. ${ }^{118}$

The notion of the President as the principal agent of the country in foreign relations finds support in several Supreme Court opinions. In United States v. Curtiss-Wright Export Corp., Justice Sutherland discussed "the very delicate, plenary and exclusive power of the President as the sole organ of the federal governinent in the field of imternational relations." ${ }^{\text {"119 }}$ In Youngstown

113. HALl, supra note 112 , at 17 (quoting SOFAER, supra note 100 , at 117).

114. THE FEDERALIST No. 69, supra note 63 , at 353.

115. U.S. CONST. art. II, $\S \S 2,3$. Although the President's treaty power and appointment power are subject to the advice and consent of the Senate, the power to initiate such actions remains with the President. The Senate cannot constitutionally force the President to enter any treaty or other international agreement or appoint a certain individual as ambassador, for that power is exclusively the President's. Rather, the Senate may act only in response to presidential action.

116. Id. $\$ 1$ ("I do solemnly swear (or affirm) that I will faithfully execute the Office of President of the United States, and will to the best of my Ability, preserve, protect and defend the Constitution of the United States.").

117. Id.

118. Id. \& 3. Article VI implies that the President's Article II duty to "take Care that the Laws be faithfully executed," id., mcludes the enforcement of all foreign treaties. Id. art. VI, \&2.

119. 299 U.S. 304,320 (1936). Justice Sutherland added that "[i]n this vast external realm [of foreign affairs], with its important, complicated, delicate and manifold problems, the President alone has the power to speak or listen as a representative of the nation." Id. at 319. 
Sheet \& Tube Co. v. Sawyer, Justice Jackson's concurring opinion described the role of the President as Commander in Chief: "I should indulge the widest latitude of interpretation to sustain his exclusive function to command the instruments of national force, at least when turned against the outside world for the security of our society." ${ }^{20}$ The Court, in another decision, has also noted that "[t]he powers of the President in the conduct of foreign relations include[] the power, without consent of the Senate, to determine the public policy of the United States."121

Further, the constitutionahty of a presidential order for a reprisal attack in a LIC situation has been upheld by a U.S. circuit court of appeals. In Durand v. Hollins, the Secretary of the Navy ordered the U.S.S. Cyane to boinbard the city of Greytown, Nicaragua, in response to an assault against a U.S. diplomat. ${ }^{122}$ In upholding the President's authority to order such an attack, the court opined that "the president is made the only legitimate organ of the general government, to open and carry on correspondence or negotiations with foreign nations, in inatters concerning the interests of the country or of its citizens." 123 The court concluded that U.S. citizens abroad are entitled to protection against acts or threats of violence to themselves or their property and that the "duty [to provide such protection] inust ... rest in the discretion of the president."124 The court cited as the basis for its decision the President's executive power, authority as Commander in Chief, and duty to execute faithfully the laws. ${ }^{125}$

In In re Neagle, ${ }^{126}$ the Supreine Court addressed the scope of the Article II clause that requires the President to "take Care that the Laws be faithfully executed."127 One question facing the Court was whether the President's duty to execute the law was

limited to the enforcement of acts of Congress or of treaties of the United States according to their express terms, or [whether it included] the rights, duties and obligations growing out of the

120. 343 U.S. 579, 645 (1952) (Jackson, J., concurring).

121. United States v. Pink, 315 U.S. 203, 229 (1942).

122. 8 F. Cas. 111, 111 (C.C.S.D.N.Y. 1860) (No. 4186).

123. Id. at 112 .

124. Id. The Durand holding has been criticized, however. See, e.g., Raoul Berger, Protection of Americans Abroad, 44 U. CIN. L. REV. 741, 741-43 (1975).

125. Durand, 8 F. Cas. at 112.

126. 135 U.S. 1 (1890).

127. U.S. CONST. art. II, § 3. 
Constitution itself, our international relations, and all the protection implied by the nature of the government under the Constitution. ${ }^{128}$

Although Neagle concerned a dispute over domestic law, ${ }^{129}$ Justice Miller referred to the "Koszta mcident" in his opinion. ${ }^{130}$ The Court implied that the actions taken by the President and U.S. military forces in tliat incident were legitimate despite the absence of any statutory authorization. ${ }^{131}$ In dissent, Justice Lainar argued that the President could not act in an executive capacity without statutory authority froin Congress, but he distinguished between doinestic and foreign affairs, thereby agreeing with Justice Miller that the Koszta incident "was justified because it pertained to the foreign relations of the United States."132

The opimions in Curtiss-Wright and Youngstown reflect judicial consideration of the customary exercise of presidential autliority in constitutional analysis. As Justice Frankfurter noted in lis concurrence in Youngstown, "It is an inadmissibly narrow conception of American constitutional law to confine it to the words of the Constitution and to disregard the gloss which life has written upon them."133 Subsequently, the Supreme Court applied a theory of customary law to constitutional analysis under Youngstown in

128. Neagle, 135 U.S. at 64.

129. The immediate issue in Neagle was whether the President was authorized to assign U.S. marshals as security agents to protect Supreme Court Justice Field while traveling on circuit assignment in California. See id. at 58-59.

130. Id. at 64. Martin Koszta was a native of Hungary who, although not yet fully naturalized as a U.S. citizen, had made a lawful declaration of intention. Koszta was seized in Smyrna on the orders of the Austrian counsel general and was confined on the Austrian vessel Hussar. However, the U.S. warship St. Louis, under the command of Captain Ingraham, had just arrived in Smyrna. After determining that Koszta had possession of the proper naturalization papers, Ingraham demanded that the Austrians turn over custody of Koszta to the United States. When the Austrians failed to respond, Ingraham was "compelled" to train his weapons on the Austrian ship before his demand for the release of Koszta was met. Id.

131. Id.

132. Id. at 84 (Lamar, J., dissenting).

133. Youngstown Sheet \& Tube Co. v. Sawyer, 343 U.S. 579, 610 (1952) (Frankfurter, J., concurring). Justice Frankfurter, in further recognizing the role of historical custom in constitutional analysis, commented that

a systematic, unbroken, executive practice, long pursued to the knowledge of the Congress and never before questioned, engaged in by Presidents who have also sworn to uphold the Constitution, making as it were such exercise of power part of the structure of our governinent, may be treated as a gloss on "execId. utive Power" vested in the President by $\$ 1$ of Art. II. 
Dames \& Moore v. Regan. ${ }^{134}$ The Court noted that the failure of Congress to delegate specific authority to the President does not imply congressional disapproval of presidential actions, especially when the actions involve foreign policy or national security and when there is "no contrary indication of legislative intent" and there is a "history of congressional acquiescence in conduct of the sort engaged in by the President." 135 Thus, it would be appropriate to consider the historical and customary use of U.S. military forces by the President in LIC situations in the constitutional analysis of presidential power.

Consideration of LIC in the framework of Justice Jackson's three-part analysis in Youngstown $n^{136}$ indicates that the deployment of U.S. military forces is not an exclusive presidential function. ${ }^{137}$ The issue is under which of Justice Jackson's categories of either exclusive congressional authority or concurrent authority sliared by the President and Congress the use of U.S. military forces in LIC would fall. The custoinary use of U.S. military forces in LIC situations since 1789 through unilateral presidential action may liave given rise to presidential authority under the Constitution to deploy suclı forces under Justice Jackson's middle category of concurrent authority.

There is little doubt that the material effects of the exercise of the President's authority as Commander in Chief lave increased since the enactment of the Constitution, given the sheer size, firepower, and capability of the present-day U.S. military. ${ }^{138}$ The

134. 453 U.S. 654 (1981). In Dames \& Moore, the plaintiff challenged several executive orders and regulations issued by President Reagan that "nullified attachments and liens on Iranian assets in the United States, directed that these assets be transferred to Iran, and suspended claims against Iran that may be presented to an International Claims Tribunal" pursuant to an executive agreement with Iran. Id. at 660 . The executive agreement with Iran, entered into by President Carter, was the result of a negotiated settlement in which 52 U.S. citizens who had been held hostage simce November 1979 were released. Id. at 664-66.

135. Id. at 678-79 (citing Haig v. Agee, 453 U.S. 280, 291 (1981)).

136. See supra notes $72-76$ and accompanying text.

137. In this sense, Congress retains some control over the military through its appropriations and auxiliary war powers. While there are limits to such authority, such as the fact that Congress cannot dictate tactical military maneuvers through legislation, see $E x$ Parte Milligan, 71 U.S. (4 Wall.) 2, 139 (1866) (prohibiting congressional interference with presidential coininand of forces and conduct of campaigus), Congress has the ultinate constitutional authority to create and maintain the military, and such authority may not be divested from Congress except by constitutional amendment. U.S. CoNST. art. I, $\S 8$, cls. 11-13.

138. See Fisher, supra note 63, at 11; see also Glennon \& Hayward, supra note 112, 
President's authority has been supplemented by customary use of U.S. military forces in LIC actions without congressional authorization. ${ }^{139}$ In the nineteenth century, U.S. military forces were used to suppress Indian tribes, piracy, and the slave trade, to pursue criminals into foreign nations, and to protect U.S. citizens and property abroad when the indigenous governments were unable to do so. ${ }^{140}$ During the early twentieth century, presidential deployment of forces in LIC operations without congressional authorization included initiatives in the Boxer Rebellion, the Panamanian rebellion against Colombia, the pursuit of Pancho Villa in Mexico, and situations in the Dominican Republic, Haiti, Cuba, Nicaragua, and the Bolshevik revolution in Russia. ${ }^{141}$ Before the U.S. declaration of war against Nazi Germany, President Franklin Roosevelt initiated inany unilateral inilitary actions, including ordering U.S. naval warships to destroy any Axis forces encountered in the North Atlantic. ${ }^{142}$

In 1977, Professor Abraham Sofaer, testifying before the Senate regarding proposed amendments to the War Powers Resolution, developed a coinparative historical analysis of the exercise of presidential authority for deploying military forces. ${ }^{143} \mathrm{He}$ concluded that the "war powers were exercised in roughly the saine manner during the first 40 years of our history as they have been exercised during inuch of the last 40 years." ${ }^{144}$ Moreover, he noted that in both periods the President had been accorded wide discretion in the conduct of foreign affairs and had "exercised

at $1590-93$.

139. As Louis Fisher observed, although Congress has formally declared war several times in U.S. history,

Presidents [have] used force on many lesser occasions, often without authorization froin Congress. A hist of such actions probably contains over two hundred actions. Anyone examining this list will conclude, as did the presidential scholar Edward S. Corwin, that they consist largely of "fights with pirates, landings of small naval contingents on barbarous or semi-barbarous coasts, the dispatch of small bodies of troops to chase bandits or cattle rustlers across the Mexican border, and the like."

Fisher, supra note 63, at 19-20 (quoting Edward S. Corwin, The President's Power, NEw REPUBLIC, Jan. 29, 1951, at 16).

140. Thomas \& Thomas, supra note 98 , at 11.

141. Id. at 13-17.

142. HALL, supra note 112 , at 45 ; THOMAS \& THOMAS, supra note 98 , at 18.

143. War Powers Resolution: Hearings Before the Senate Comm. on Foreign Relations, 95th Cong., 1st Sess. 86-90, 101-08 (1977) (testimony of Professor Abraham D. Sofaer, Columbia University School of Law).

144. Id. at 89. 
independence and leadership even in the absence of clear legislative authority, and sometimes despite the presence of apparently inconsistent legislative direction."

\section{B. Allocating Authority Between the President and Congress to Deploy Military Forces in LIC}

In light of the competing interests of the President and Congress, as well as the historical influences of the intent of the Framers and the development of customary usage of U.S. military forces, there is no definitive answer to the question of where the power to engage in LIC rests. However, as LIC has been conducted over tle past two hundred years, it is apparent that practical considerations have allowed both branches of government to play a role witlı respect to LIC. The most reasonable resolution would allow the use of a presidential prerogative to deploy U.S. military forces im LIC, subject to congressional authority that could limit or terminate the President's ability to engage in LIC either preemptively or after deployment. ${ }^{146}$

1. Inconclusive Interpretation of Constitutional Authority to Deploy Military Forces. The relatively brief debate and commentary surrounding the war powers at the Constitutional Convention slieds little hight on the intent of the Franers. ${ }^{147}$ While certain principles with regard to the use of force espoused by the Framers are clear, they are not particularly helpful with respect to LIC. $^{148}$ Similarly, the debate at the Constitutional

145. Id. at 109 .

146. This approach has been described as a "political accommodation model." Jane E. Stromseth, Rethinking War Powers: Congress, the President, and the United Nations, 81 GEO. L.J. 597, 664-66 (1993). However, Stromseth applied her analysis only to situations in which the President has authority pursuant to a U.N. Security Council resolution. Id. at 665. But see supra note 5. Under the political acconmodation model, while congressional authorization would be required when "U.S. troops are committed to combat in substantial numbers because the risk of great physical sacrifice-of war-is real," the President could authorize the use of U.S. military forces for sunall-scale actions involving minimal risk of escalation. Stromseth, supra, at 664; see also Raven-Hansen, supra note 111 , at 41 (distinguishing between "wholesale" and "retail" military actions); Note, Congress, the President, and the Power to Commit Forces to Combat, 81 HARV. L. REV. 1771, 1795-96 (1968).

147. See supra notes $82-89,112-118$ and accompanying text.

148. Among such principles are that the Constitution places institutional checks on the power of the United States to declare war; that the President has the unilateral authority to repel sudden attacks; that once war is commenced, the President is military command- 
Convention was ambiguous as to whether the authority to deploy U.S. military forces abroad in LIC situations is vested exclusively within Congress, because the debate failed to elaborate on "the scope of presidential authority in ordering defensive measures [or] the point at which defensive ineasures become offensive warfare." 149

As executive practice unfolded during the nineteenth and early twentieth centuries, the lack of conclusiveness with respect to authority to deploy military forces in LIC led to the view that such authority was primarily a presidential responsibility. By 1940, the Small Wars Manual issued by the U.S. Marine Corps held the view that the President had the power to use military force unilaterally to protect U.S. hives and property abroad. ${ }^{150}$ Despite the more activist role played by Congress over control of U.S. military deployments in LIC situations and the passage of the War Powers Resolution in 1973, no President in the latter half of the twentieth century has openly relinquished all authority to deploy military forces to congressional supremacy. Furthermore, the argument for

er; and that Congress has the responsibility for providing and funding military forces. HALL, supra note 112, at 32-33; Raven-Hansen, supra note 111, at 30-31; see EDWARD KEYNES, UNDECLARED WAR 56-57 (1982).

149. KEYNES, supra note 148 , at 36 .

150. The Small Wars Manual states,

According to international law ... a nation may protect, or demand protection for, its citizens and their property wherever situated. The President of the United States as the Chief Executive is, under the Constitution, primarily charged with the conduct of foreign relations, including the protection of the lives and property of United States citizens abroad, save insolar as the Constitution expressly vests a part of these functions in some other branch of the Government. . . It has been an unbroken policy of the President of the United States so to interpret their powers, beginning with the time of President Jefferson down to the present with the exception of President Buchanan.

U.S. MARINE CoRPS, supra note 1, ch. 1, \$1-3(a). The Small Wars Manual, in rejecting any notion of congressional supremacy regarding the deployment of forces in LIC, argues that "[t]he use of the forces of the United States in foreign countries to protect the lives and property of American citizens resident in those countries does not necessarily constitute an act of war, and is, therefore, not equivalent to a declaration of war." Id. I $1-3(c)$.

The apparent rejection of presidential prerogative by President Buchanan stems from several incidents. In 1857, he declined to contribute military forces to an AngloFrench operation in China on the grounds that it was an act of war that required congressional authorization. THOMAS \& THOMAS, supra note 98, at 33. On another occasion, President Buchanan requested congressional approval for the use of force because of a belief that the President "cannot legitimately resort to force without the direct authority of Congress except in resisting and repelling attacks." Id. (quoting Richard A. Putney, Executive Assumption of the War Making Power, 7 NAT'L L. REV. 1, 15 (1927)). 
presidential prerogative has been advanced by the lack of any significant judicial decisions ruling against executive autlıority. Witlı the exception of sporadic cases, the federal courts, on the grounds of justiciability, have been reluctant to issue decisions and opinions clarifying the respective constitutional powers of botli branches. ${ }^{151}$

Addressing the lack of conclusiveness about the allocation of authority between the President and Congress witli respect to the deployment and use of U.S. nilitary forces, Professor John Norton Moore lias identified several general nıodels, subject to nunierous variations, to describe the balance of power. ${ }^{152}$ These would include concurrent presidential authority (i.e., the President sliares the war-inaking power with Congress); exclusive congressional authority (i.e., the President nuay not use any military force in the absence of congressional approval); requirement of congressional autlorization for sustained lostilities involving conibat forces; and presidential authority for defensive wars, but not for offensive wars. ${ }^{153}$ Thus, the notion that the President lias the prerogative to engage unilaterally in LIC would be consistent witl the first and third models but not with the second and fourth.

2. Defining Concurrent Authority Under Youngstown. An analysis of war powers under Justice Jackson's concurrence in Youngstown can be helpful in determining whetler the President has independent autliority to initiate a LIC. ${ }^{154}$ Since it is clear that the President may carry out a LIC under Jackson's first category, in consonance with congressional approval and legislation, ${ }^{155}$ the issue is whether the President may execute a LIC congressional authorization. ${ }^{156}$ If there is no concurrent au-

151. Harold H. Koh, Why the President (Almost) Always Wins in Foreign Affairs: Lessons of the Iran-Contra Affair, 97 YALE L.J. 1255, 1313-17 (1988).

152. John N. Moore, Emergency War Powers, in THE U.S. CONSTITUTION AND THE POWER TO Go To WAR, supra note 63 , at $159,160-61$.

153. Id. Moore's personal view is the third model. Id. Each model, including the interpretation that supports exclusive congressional authority, would permit the President to respond to a direct attack on U.S. territory or U.S. forces stationed abroad without congressional approval. See id.

154. See supra notes $72-76$ and accompanying text.

155. See supra notes $93-95$ and accompanying text.

156. The question, in other words, is whether the authority to initiate a LIC lies within Jackson's second category of shared authority ("zone of twilight"), Youngstown Sheet \& Tube Co. v. Sawyer, 343 U.S. 579, 637 (1952) (Jackson, J., concurring), or represents an exclusive congressional power. 
thority for the President to conduct military deployments in LIC, then by default the President may rely only on independent constitutional authority. Commentators who support presidential authority would generally place LIC in Jackson's "zone of twilight," while those who support congressional exclusivity would place LIC in Jackson's third category, in which presidential power is "at its lowest ebb."157

Two competing theories in which analysis under Jackson's Youngstown concurrence can take place have been identified by one commentator. ${ }^{158}$ The first theory, based on distinguishing between defensive and offensive war, is grounded on interpreting the implications of the Framers that the President had the ability to fight a defensive war, but could not launch an offensive war. ${ }^{159}$ The second theory is a threshold approach based on the scale of military forces used and the duration of hostilities. ${ }^{160}$

157. Id.

158. KEYNES, supra note 148 , at $88-91$.

159. Id. at 88. Keynes adds that the defensive/offensive war theory turns on two factors: the "character" of military hostilities (which presumes that certain military operations can be labeled as either "offensive" or "defensive") and the duration of the conflict. Id. at $88-89$.

160. See id. at 90-91. Keynes identifies, in a table, "An Array of Military and Diplomatic Actions in Order of Ascending Magnitude":

1. Covert intelligence operations and clandestine paramilitary operations

2. Diplomatic actions that imply subsequent military operations, e.g., severing diplomatic relations

3. Deployment of armed forces in nonhostile situations, e.g., rotation of troops to meet alliance commitments

4. Mobilization of military forces, e.g., call up of army reserves

5. Deployment of armed forces in hostile situations, e.g., commitment of armed forces to combat zones

6. Limited military engagements, e.g., protection of U.S. citizens, property, and public ships, seizures, and reprisals

7. Limited military interventions, e.g., civil commotions, claims settlements, border disputes, and preemption of third-party interventions

8. Material wars, i.e., undeclared wars: the Naval War with France, the Barbary Wars, the Civil War, the Korean War, and the Vietnam War

9. Publicly declared wars: the War of 1812, the Mexican War of 1846-1848, the Spanish American War of 1898, World War One, and World War Two.

Id. 'Keynes, in describing the threshold theory, asserts that actions 1 through 4 fall within pure presidential discretion, while action 9 falls within the exclusive authority of the Congress. Actions 5 through 8 fall into a gray area of war powers, and the President's authority to take such actions would depend on congressional actions and analysis under Jackson's concurrence. Id. at 90-91.

In comparing contemporary definitions of LIC with the military and diplomatic actions identified by Keynes, actions 1 through 7 would generally be considered low-intensity, while actions 8 and 9 would correlate, respectively, to mid-intensity conflict and high- 
The use of the defensive/offensive theory that was developed during the time of the Framers contains numerous flaws that make it difficult to apply in the modern context. First, determining whether a particular action taken by the United States is defenseor offense-oriented is often problematic, since such a determination often depends on which perspective the observer takes. ${ }^{161}$ As a result, if one is creative enough, almost any type of conflict can be characterized as defensive. ${ }^{162}$ Second, the defensive/offensive theory fails to distinguish between actions taken at the strategic level and those taken at the tactical level. ${ }^{163}$ Third, the defensive/offensive theory has difficulty in providing meamingful guidance as to when the President inay "defend" allied foreign nations, ${ }^{164}$ inchoate U.S. security interests, ${ }^{165}$ or international law in pohice actions. ${ }^{166}$ Fourth, since the U.N. Charter specifically outlaws offensive war, ${ }^{167}$ it is unlikely that the United States, or any nation, would ever characterize a military action as offensive, or aggressive, in nature. ${ }^{168}$

In applying Jackson's concurrence in Youngstown to war powers with respect to LIC, a President, in order to take action, must have either concurrent authority or independent authority. Concurrent authority, as described by Jackson, may exist when there is a "zone of twilight" in which the distribution of authority to take such action between the President and Congress is uncertain. ${ }^{169}$

intensity conflict. See supra Part I.

161. See KEYNES, supra note 148 , at 49 ; id. at $88-89$ (giving as an example the question of whether the forward deployment of neutron weapons in Europe by the United States during the 1980s was offensive or defensive).

162. See, e.g., O'BRIEN, supra note 10, at 99-130 (describing the arguments offered as to whether the use of reprisals by Israel in its counterterrorism campaign agamst Palestinians was an act of self-defense).

163. The strategic level represents the overall political and military objective or mission of the operation, while the tactical level refers to the methods used to achieve such objectives. See HARry G. SUMmers, JR., ON STRATEGY II, at 183-84 (1992). Thus, it is possible to have an operation that is tactically offensive but strategically defensive. Id. at 183. For instance, the conflict in Vietnam was defensive at the strategic level (i.e., the objective was to prevent the fall of South Vietnam, not to capture North Vietnam), but was often fought offensively at the tactical level (e.g., the 1970 incursion into Cambodia).

164. See Raven-Hansen, supra note 111 , at $40-41$.

165. See id. at $42-43$.

166. See id.

167. See U.N. CHARTER art. 2, I 4.

168. See Congressional Hearings, supra note 89, at 276 (statement of Professor Robert F. Turner, University of Virginia School of Law).

169. Youngstown Sheet \& Tube Co. v. Sawyer, 343 U.S. 579, 637 (1952) (Jackson, J., 
Thus, because the separation of powers with respect to LIC and war powers is unclear, one must apply a separate test to see if in fact the President does have concurrent authority.

The second test is whether "congressional inertia, indifference or quiescence" has, as a practical nnatter, enabled or invited "independent presidential responsibility."170 Justice Jackson observed that "any actual test of power is likely to depend on the inperatives of events and contemporary imponderables rather than on abstract theories of law."171 In Dames \& Moore, the Supreme Court further held that "the enactment of legislation closely related to the question of the President's authority in a particular case which evinces legislative intent to accord the President broad discretion" may invite independent presidential responsibility under Jackson's Youngstown concurrence, if there is a history of congressional acquiescence and no contrary indication of legislative intent. $^{172}$

As to the second test in Youngstown, Justice Jackson found that President Truman's seizure of the steel mills was not warranted under concurrent authority, because his actions were inconsistent with the legislation passed by Congress that specifically addressed such situations. ${ }^{173}$ One could argue analogously that the passage of the War Powers Resolution by Congress in $1973^{174}$ has reinoved any concurrent authority of the President to deploy military forces in LIC. ${ }^{175}$ In fact, the legislative history of the War Powers Resolution noted that the law specifically attempted

concurring).

170. Id.

171. Id.

172. Dames \& Moore v. Regan, 453 U.S. 654, 678 (1981); see supra notes 21, 71.

173. Youngstown, 343 U.S. at 639.

174. War Powers Resolution, Pub. L. No. 93-148, 87 Stat. 555 (1973) (codified at 50 U.S.C. $\$ \S 1541-1548$ (1988 \& Supp. V 1993)).

175. Section 4(a)(1) of the War Powers Resolution requires the President to submit a report to Congress within 48 hours if U.S. military forces are introduced "into hostilities or into situations where inminent imvolvement in hostilities is clearly indicated by the circumstances" in the absence of a declaration of war. 50 U.S.C. $\& 1543(a)(1)$ (1988). Under $\S 5(b)$, the President must remove all U.S. military forces introduced into circumstances covered by $\& 4(a)(1)$ within 60 days (or 90 days if the President certifies to Congress that the additional time is required in order to achieve safely the removal of U.S. military forces) after the report was submitted or was required to be submitted, whichever is earlier, unless Congress has declared war, extended this time period, or is physically unable to meet. Id. $\S 1544(\mathrm{~b})$ (1988). 
to prevent the President from asserting concurrent authority with respect to war powers under Youngstown. ${ }^{176}$

Nevertheless, the interpretation that the War Powers Resolution removed concurrent authority of the President to deploy U.S. military forces in LIC should be rejected for several reasons. First, Youngstown addressed a domestic situation, and the Court has generally acknowledged broader presidential discretion in the area of foreign affairs. ${ }^{177}$ Second, the legislative history of the War Powers Resolution demonstrates that it was concerned primarily with mid- and high-intensity conflict, such as the U.S. experience in Vietnam, rather than with LIC. ${ }^{178}$ Third, by granting the President the power to engage in any hostility, including offensive actions, for up to ninety days, the War Powers Resolution implies that there must be some concurrent or independent presidential war powers. ${ }^{179}$ Fourth, an examination of congressional indiffer-

176. The Senate Report on the War Powers Resolution stated,

A President can hardly be blamed if ... he regards an effort by Congress to reassert powers which it has long neglected to exercise as an attempt to infringe upon his own powers.

All of which is by way of making the point that it is far more difficult to reassert a power which has been permitted to atrophy than to defend one which has been habitually nsed. The Congress accordingly bears a heavy responsibility for its passive acquiescence in the unwarranted expansion of Presidential power. As the late Justice Robert $\mathrm{H}$. Jackson pointed out in his concurring opinion in Youngstown v. Saywer, there is a "zone of twilight" between the discrete areas of Presidential and Congressional power. Politics, hike nature, abhors a vacuum. When Congress created a vacuum by failing to defend and exercise its powers, the President inevitably hastened to fill it.

S. REP. No. 220, 93rd Cong., 1st Sess. 16 (1973).

177. Haig v. Agee, 453 U.S. 280,291 (1981) (" $[1] \mathrm{n}$ the areas of foreign policy and national security, ... congressional silence is not to be equated with congressional disapproval."); see Dames \& Moore v. Reagan, 453 U.S. 654, 669 (1981) (noting that "[t]his is particularly true as respects cases ... involving responses to international crises the nature of which Congress can hardly have been expected to anticipate in any detail"); see also supra notes 116-18 and accompanying text.

178. S. REP. No. 220 , supra note 176, at 2-4; see H. REP. No. 287, 93rd Cong., 1st Sess. 3-4 (1973), reprinted in 1973 U.S.C.C.A.N. 2346, 2348 (observing that the primary catalyst for the War Powers Resolution was the President's authorization of military operations inside the Cambodian border during the Vietnam confiict). Interestingly, an earlier version of the War Powers Resolution considered by the Senate in 1973 would have given the President the authority to comnit military force to hostilities to rescue U.S. citizens and to forestall the direct threat of attack against the United States or U.S. military forces abroad. Ellen C. Collier, Statutory Constraints: The War Powers Resolution, in THE U.S. CONSTITUTION AND THE POWER TO GO TO WAR, supra note 63, at 55, 57. However, such provisions were dropped during conference between the House and Senate on the final version of the bill. Id. at 57-58.

179. See supra note 105. 
ence and acquiescence as a practical matter suggests that Congress has failed to enforce strictly presidential compliance with the provisions of the War Powers Resolution, especially in light of the numbers and types of uses of military force by Presidents in LIC situations since $1973 .{ }^{180}$

3. Considerations That Favor Presidential Prerogative to Initiate LIC. The practical reasons for allowing presidential prerogative in initiatimg and conducting LIC he largely in the inherent abihity of the executive branch to determine appropriate foreign pohcy. ${ }^{181}$ The President, elected by the entire nation and head of the diplomatic, military, and intelligence structure, is often in a better position to determine foreign policy than inembers of Congress. The executive branch is also much more likely to exhibit the traits, such as decisiveness, dispatch, unity, and secrecy, required for a successful LIC than is Congress. ${ }^{182}$ Furthermore, if the President were constrained until Congress were to pass legislation authorizmg certain actions, a step that Congress is not required to take, U.S. policy might result in "no policy," with potentially worse consequences. Thus, in practical terms, the President has the institutional and pohtical advantage in making an initial, unilateral determination to deploy U.S. inilitary forces, a choice that is often difficult for Congress to reverse. ${ }^{183}$

The inost common policy argument against presidential prerogative $\mathrm{m}$ the context of LIC is the fear that LIC involvement inay lead the United States into a more general state, or escalation, of hostilities. ${ }^{184}$ To date, most of the controversy has cen-

180. See Collier, supra note 178 , at $61-63$; see also ELY, supra note 109 , at $48-49$ (describing Congress's failure to invoke the War Powers Resolution since Vietnam).

181. See, e.g., Dames \& Moore, 453 U.S. at 678-80; United States v. Pink, 315 U.S. 203, 229-30 (1941); United States v. Curtiss-Wright Export Corp., 299 U.S. 304, 319 (1936).

182. See Theodore C. Sorensen, Political Perspective: Who Speaks for the National Interest, in THE TETHEREd PREsidenCY 3, 3-20 (Thomas M. Franck ed., 1981). Sorensen concludes,

In short, a supine presidency has no more to recommend it in the foreign affairs arena than an imperial presidency. The framers of the Constitution wanted the president's power to be shared, balanced, and held accountable. But they also knew, after brief experience with the Articles of Confederation, that decisive, unified initiative and implementation in foreign affairs were properly the Id. at 14. prerogative of a single, nationally elected executive.

183. MARC E. SMYRL, CONFLICT OR CODETERMINATION?: CONGResS, THE PRESIDENT, AND THE POWER TO MAKE WAR 142 (1988).

184. See Lobel, supra note 86, at 1088-89 (claiming that "the dispatch of American 
tered on the necessity of receiving prior congressional approval before deployment in a LIC situation. ${ }^{185}$ However, since a LIC is not necessarily a combat situation or even hostile at all, it is questionable whether LIC falls under the jurisdiction of congressional war powers. ${ }^{186}$ Furthermore, arguments surrounding the risk of escalation have tended to reflect only the U.S. experience in Vietnam, when in fact neither historical experience since 1975, such as events in Central America, nor pre-Vietnam LIC deployments support such a preinise. ${ }^{187}$ While the risk of escalation is real, Congress should have sufficient lead time to react to or to preempt presidential escalations from LIC, since military deployment into a LIC is often considered as a policy alternative long before actual deployment. ${ }^{188}$

military advisors or small troop detachinents ... [has] a strong tendency to escalate into a larger American role involving United States troops").

185. See, e.g., CONGRESSIONAL REPORT, supra note 24 , at 82 . The report observed that the War Powers Resolution "hypothetically applied to several cases in this study, but the Supreme Court has never ruled on constitutionality and they have not been put to serious test. Nevertheless, they constrain U.S. courses of action." Id.

186. Section 4(a) of the War Powers Resolution, for instance, sets forth three situations in which deployment of U.S. armed forces will activate its reporting provisions, under which the President inust file a report to Congress within 48 hours:

(1) [deployment] into hostilities or into situations where inminent involvement

in hostilities is clearly indicated by the circuunstances;

(2) [deployment] into the territory, airspace or waters of a foreign nation, while equipped for coinbat, except for deployments which relate solely to supply, replacement, repair, or training of such forces; or

(3) [deployment] in numbers which substantially enlarge United States Armed Forces equipped for combat already located in a foreign nation.

50 U.S.C. \& 1543(a) (1988). However, only conditions under $\$ 4(a)(1)$ trigger the automatic withdrawal provisions of $\S 5$ of the War Powers Resolution. There has been considerable debate as to where the authority of Congress's war powers end and the President's Commander in Chief powers begin, especially as outlined in § 4(a). While it is clear that Congress may invoke its war powers in regards to a decision to enter into hostilities in a situation such as the Vietnam conflict or Operation Desert Storm, it is less apparent when a deployment of U.S. armed forces appears not to involve imminent hostilities.

187. The underlying premise is an escalation froin a LIC to a mid- or high-intensity conflict. On the other hand, if one considers "escalation" to inean any change in U.S. military objectives while staying withm the context of LIC, then one may encounter "mission creep." Mission creep occurs when the goals of the inilitary forces are changed in the midst of a deployment, such as when a "humanitarian assistance" mission turns into a "peace enforcement" operation. But if the President has authorization to commit U.S. military forces for any LIC originally, then the change in mission, so long as it stays within the reaim of LIC, does not affect his authority or the legitimacy of the deployment. Should Congress become alarmed at the change in mission, its proper response would be to pass legislation either to limit or to terminate the deployment.

188. See infra note 234 and accompanying text. 
A 1990 study of sixty twentieth-century LICs, commissioned by Congress, noted that only twenty-two involved U.S. military combat, and that of these, almost half took place before $1945 .^{189}$ Thus, out of the forty-seven LIC actions since World War II, the vast majority either have not mvolved U.S. military units or, where such units have been deployed, have not involved combat operations. ${ }^{190}$ During congressional testimony on war powers in 1971, Professor Moore stated that during the eighteenth and nineteenth centuries, there were approximately one hundred deployments of U.S. military units abroad, and that of this number Congress had fully authorized only a small handful. ${ }^{191}$ Moore observed that "Inost of these mstances were relatively ninor actions for the protection of nationals, for the suppression of pirates, or for the punishment of violations of international law."192

Moore concluded that Congress has the authority to limit the President's use of U.S. nuilitary units in areas that fall "within exclusive congressional authority," such as the deployment of combat forces into sustained hostilities abroad. ${ }^{193}$ However, areas in which Congress does not have exclusive authority, such as foreign relations, suggest the existence of some independent power within the executive branch. ${ }^{194}$ This mherent presidential authority allows the minor use of force to conduct certain low-mtensity operations and limits congressional ability to interfere with such use, except in extreme cases of presidential abuse. ${ }^{195}$

189. CONGRESSIONAL REPORT, supra note 24, at 23-26.

190. Id. at 25. In instances in which no U.S. military units were involved, the report found that sanctions and security assistance were the basic instruments applied in LIC actions. Id. at 26. However, in several instances in which U.S. military units were deployed but were not involved in combat, it was clear the United States intended to use the threat of force to assist in accomplishing its objectives through other means (i.e., political or diplomatic). See id. at 23.

191. War Powers Legislation: Hearings Before the Senate Comm. on Foreign Relations, 92d Cong., 1st Sess. 463 (1971) (testimony of Professor John N. Moore, University of Virginia School of Law). The few instances that were authorized by Congress include three declared wars (the War of 1812, the Mexican-American War, and the SpanishAmerican War) and the undeclared naval war with France. Id.

192. Id.

193. Id. at 470 .

194. See id.

195. Id. Thus, Moore concluded that the President has independent authority to engage in LIC for such missions as

regional peacekeeping, actions in defense of United States interests in free transit of international straits, humanitarian interventions such as the Stanleyville operation, defensive quarantines such as were involved in the Cuban missile crisis, and the commitment of military assistance advisory groups provided that 
In 1975, Congress held liearings regarding presidential compliance with the War Powers Resolution. In the aftermath of the passage of the Resolution in 1973, President Ford liad deployed U.S. military forces in several LIC actions. ${ }^{196}$ Monroe Leigl,, legal advisor to the State Department, conceded in his testimony at the hearings that the President would have to withdraw from a LIC if Congress chose to terminate funding for that operation. ${ }^{197}$ But Leigh also argued that if there is no specific congressional legislation or if the President lias funding available from a prior appropriation, the President has the autliority to conduct a LIC, and if necessary, mtroduce U.S. military forces. ${ }^{198}$

In 1986, Professor Sofaer returned as the State Department legal advisor to testify before Congress, which was holding hearings on war powers in light of LIC-type retaliatory strikes on Libya. ${ }^{199} \mathrm{He}$ commented that the miposition of arbitrary and inflexible deadlines, sucl as those found in the War Powers Resolution, creates "unwise limitations" on the President's power to deploy U.S. military forces for national security interests. ${ }^{200}$ Fur-

such commitments stop short of the commitment of regular combat units to sustained hostilities.

Id.

196. These actions were the evacuation of U.S. nationals and others from Cambodia and South Vietnam in light of advancing commumist forces and the rescue of the U.S. crew of the S.S. Mayaguez, who had been taken hostage by Cambodian forces. COLLIER, supra note 4 , at 18.

197. War Powers: A Test of Compliance: Hearings Before the Subcomm. on Int'l Security and Scientific Affairs, House Comm. on Int'l Relations, 94th Cong., 1st Sess. 89 (1975) (statement of Monroe Leigh, legal advisor to the Department of State).

198. Id. Leigh was asked whether there were any situations other than those listed in \& 2(c) of the War Powers Resolution, 50 U.S.C. $\& 1541$ (1988) (i.e., declaration of war, specific statutory authorization, and national emergency created by attack on U.S. territory or armed forces), in which the President has inherent constitutional authority to use U.S. military forces. While arguing that his list was by no means exhaustive, Leigh suggested that the President has such authority

to rescue American citizens abroad, to rescue foreign nationals where such action directly facilitates the rescue of U.S. citizens abroad, to protect U.S. Embassies and Legations abroad, to suppress civil insurrection, to implement and administer the terms of an armistice or cease-fire designed to terminate hostilities involving the United States, and to carry out the terms of security commitnents contained in treaties.

Id. at 90 .

199. War Powers, Libya, and State-Sponsored Terrorism: Hearings Before the Subcomm. on Arms Control, Int'l Security and Science of the House Comm. on Foreign Affairs, 99th Cong., 2d Sess. 5-61 (1986) [hereinafter War Powers Hearings] (testimony of Abraham D. Sofaer, legal advisor to the Department of State); see supra note 143.

200. War Powers Hearings, supra note 199, at 17. Professor Sofaer argued, 
thermore, Sofaer stated that "[w]e doubt that the resolution should in general be construed to apply to the deployment of such antiterrorist units where operations of a traditional military character are not conteinplated, and where no confrontation is expected between our units and forces of another state."201

\section{Criticism of Exclusive Congressional Authority over} LIC. As the Supreme Court recognized in Curtiss-Wright, the United States, as a sovereign nation, has certain inherent rights of sovereignty under international law. ${ }^{202}$ In general, the authority to exercise such rights and to conduct foreign relations lies with the President, except in certain circumstances in which the Constitution has either withdrawn or placed limits on the President's authority ${ }^{203}$ Since the Constitution expressly gives the power to declare war and to issue letters of marque and reprisal to Congress, commentators who support congressional supremacy have argued that Congress has the exclusive authority to approve the use of military force and that constitutionally the President must have such approval before using force. ${ }^{204}$

The strict separation of the nuilitary and diplomatic functions between Congress and the President would create an unworkable division in the conduct of foreign relations. As Clausewitz has observed, the use of military force is just a subset of foreign relations. ${ }^{205}$ Nevertheless, because of the extreme nature of the decision to declare war, the Frainers of the Constitution sought to place institutional constraints on this decision by requiring the approval of both houses of Congress. ${ }^{206}$

Such deadlines can undermine foreign policy judgments, and adversely affect our ability safely and effectively to deploy U.S. forces in support of those judgments. . . . [Moreover, t] he President has constitutional power, as Commanderin-Chief and as the nation's principal authority for the conduct of foreign affairs, to direct and deploy U.S. forces in the exercise of self-defense, including Id. the protection of American citizens from attacks abroad.

201. Id. at 7 .

202. United States v. Curtiss-Wright Export Corp., 299 U.S. 304, 315-21 (1936).

203. For example, a treaty may become effective only with the consent of two-thirds of the Senate, U.S. CONST. art. II, $\$ 2$, cl. 2 , and only Congress may regulate international commerce, id. art. I, \& 8, cl. 3.

204. See supra subsection II(A)(1).

205. CARL VON Clausewitz, ON WAR 119 (Anatol Rapoport ed., 1968) ("War is a mere continuation of policy by other means.").

206. See supra notes $81-85$ and accompanying text. 
Nor does it necessarily follow that the Framers sought to eliminate any independent use by the President of military forces in measures short of war, such as LIC, by the grant of power delegated to Congress regarding the issuance of letters of marque and reprisal. ${ }^{207}$ Letters of marque and reprisal have not been distributed since the War of 1812, and the lack of usage of the Marque and Reprisal Clause since that period indicates that it has apparently become "anachronistic and unimportant." 208 Of more significance, however, is the historical context in which the Marque and Reprisal Clause was enacted: the United States was a sniall, relatively isolated, unindustrialized country with minimal public military forces. Thus, one could logically deduce a concern at the Constitutional Convention that even in the absence of regular military units, the President niight retain the services of private forces or militias to sidestep the Constitution's placement of the war declaration power with Congress, and plunge the country into war. Nevertheless, it would be quite a stretch of interpretation to attach such a restriction on the President's ability to use public military forces for LIC operations.

Furthermore, it would be inconsistent to prevent the President froin exercising his authority as Commander in Chief to support his conduct of foreign relations, as long as such actions did not anount to war. ${ }^{209}$ The use or threat of military force in LIC is often crucial to achieving diplomatic success in the conduct of foreign relations. ${ }^{210}$ Practical examples in which the President's

207. See supra text accompanying notes 86-90.

208. Marshall Silverberg, The Separation of Powers and Control of the CIA's Covert Operations, 68 TEX. L. REV. 575, 581 (1990).

209. For example, during the 1980s, the United States provided military advisors to El Salvador at the request of its government as part of a more general LIC campaign to contain the spread of communism in Central America. CONGRESSIONAL REPORT, supra note 24 , at 183-84. This was clearly not an act of war under international law, because the U.S. military was responding to an invitation extended by the host government. On the other hand, supporters of congressional supremacy would argue that the deployment, while not an act of war under international law, was an act that invoked congressional war powers under U.S. constitutional law.

210. The Small Wars Manual exemplifies this principle:

In small wars, either diplomacy has not been exhausted or the party that opposes the settlement of the political question cannot be reached diplomatically. Small war situations are usually a phase of, or an operation taking place concurrently with, diplomatic effort. The political authorities do not relinquish active participation in the negotions [sic] and they ordinarily continue to exert considerable influence on the military campaign. The military leader in such operations thus finds himself limited to certain lines of action as to the strategy and even as to the tactics of the campaign. This feature has been so marked in 
foreign affairs and Commander in Chief powers have coincided include U.S. involveinent in the inultinational force in Lebanon in 1982-1983, the escort of reflagged Kuwaiti oil tankers through the Persian Gulf in 1987,211 and the negotiated departure from power of the Haitian inilitary dictatorship in $1994 .^{212}$

Even if Congress were to authorize the President to initiate military action, such approval would often be contingent on a successful venture, as Congress, even when it approves the action, often atteinpts to distance itself froin military failure. The clearest example of this "cut and run" Inentality is the conflict in Vietnam, whicl some coinmentators have argued, despite political pronouncements to the contrary, was a lawful, constitutional war that would have been permitted under the War Powers Resolution had that law been in effect at the time. ${ }^{213}$ Thus, even if Congress gives its initial approval to military action, it may subsequently argue that it was misled by the executive branch or that it did not intend to grant such authority, in an effort to deny political responsibility for failure.

5. The Role of Congress with Respect to LIC When the President Has Prerogative. While the President has the prerogative to initiate and impleinent LIC tactics and strategy as part of U.S. foreign relations, Congress retains the final autlority to regulate U.S. involvement. $^{214}$ In other words, although in the absence of any

past operations, that marines have been referred to as State Department Troops in small wars. In certain cases of this kind the State Department has even dictated the size of the force to be sent to the theater of operations. The State Department materially influences the strategy and tactics by orders and instructions which are promulgated through the Navy Department or through diplomatic representatives.

U.S. MARINE CORPS, supra note 1 , at ch. 1, 1-7.

211. HALL, supra note 112 , at $148-50,250-51$.

212. President Bill Clinton, Oval Office Address Announcing an Agreement in Haiti, Federal News Service, Sept. 18, 1994, available in LEXIS, News Library, Fednew File [hereinafter Oval Office Address].

213. See ELY, supra note 109, at 12,15-23. Ely concludes that despite "years of denial and doubletalk," U.S. involvement in Vietnam was constitutionally authorized by Congress by the Gulf of Tonkin Resolution. Id. at 12 . Turner reaches the same conclusion, noting that "the commitment of U.S. Armed Forces to Vietnam was fully consistent with the current procedures of the War Powers Resolution set forth in section 2(c)(2)." Congressional Hearings, supra note 89, at 36-37, 57-63 (testimony of Professor Robert F. Turner, University of Virginia School of Law); see also Robert F. Turner, Separation of Powers in Foreign Policy: The Theoretical Underpinnings, 11 GeO. MASON U. L. REV. 97, 109, 115 (1988).

214. See Michael J. Glennon, The War Powers Resolution: Sad Record, Dismal Prom- 
congressional action, the President would have authority to conduct LIC, that authority would be subordinated to any contrary, explicit legislation passed by Congress. ${ }^{215}$ The placement of the ultimate source of authority in Congress stems from Congress's constitutional power to regulate war and foreign affairs and to appropriate funds. ${ }^{216}$ However, this interpretation of the constitutional strictures does not go so far as to require specific congressional authorization prior to engaging in a LIC. This approach reflects both Chief Justice Marshall's opimion in Little $v$. Barreme $^{217}$ and Justice Jackson's concurrence in Youngstown Sheet \& Tube Co. v. Sawyer. ${ }^{218}$

This interpretation of presidential authority over LIC also appears to be consistent with one possible construction of the War Powers Resolution. The Resolution can be interpreted as implying inherent constitutional authority for the President to initiate hostilities for a sixty- to ninety-day period before Congress autonnatically terminates such action. ${ }^{219}$ Aside froin the War Powers Resolution, it is widely agreed that Congress has the absolute authority to terminate a President-initiated LIC by eliminating all funding for the operation through its appropriation power. ${ }^{220}$ In addition,

ise, 17 LOY. L.A. L. REV. 656, 661 (1984) (observing that under the "fluctuating" powers approach, the scope of presidential authority "is a function of the concurrence or nonconcurrence of the Congress; once Congress acts, its negative provides 'the rule of the case' ").

215. See SOFAER, supra note 100 , at 166.

216. See U.S. CoNST. art I, § 8, cls. 1, 3, 11-16, 18.

217. 6 U.S. (2 Cranch) 170, 177 (1804); see supra notes 96-97 and accompanying text.

218. 343 U.S. 579, 641-46 (1952) (Jackson, J., concurring); see supra notes 72-76 and accompanying text.

219. Thomas M. Franck, After the Fall: The New Procedural Framework for Congressional Control over the War Power, 71 AM. J. INT'L L. 605, 626-27 (1977). Franck elaborates on the War Powers Resolution that

the approach to allocation of overlapping powers [between Congress and the President] to engage in war is redirected from the enumeration of instances [of when the President may initiate hostilities alone] to the speciflcation of duration [of how long such hostilities may last]. In effect, the President seems to be conceded the power, under incompletely delimited circumstances, to start short wars and Congress the power to terminate long ones.

220. See, e.g., Department of Defense Appropriations Act of 1994, Pub. L. No. 103-139, § 8151(b)(2)(B), 107 Stat. 1418, 1476-77 (1993) (enacting the Byrd amendment, which prohibited the expenditure of funds for any U.S. military operations in Somalia after March 31, 1994, without subsequent congressional action); see also supra text accompanying note 197 . 
Congress can pass legislation specifically prohibiting the President from engaging in a particular LIC. ${ }^{221}$

However, to argue for stronger authority for Congress to regulate LIC would be to severely impair the instruments available to the President in the area of foreign relations. The determination as to whether the United States should engage in a particular LIC is very fact- and circumstance-specific and must be made in an expedient manner. ${ }^{222}$ For that reason, a broad prospective prohibition on any LIC without prior congressional authorization would be untenable. ${ }^{223}$ This is particularly true when congressional concern over U.S. involvement in LIC often stems more from political expediency and the fear of being held responsible for a failed crisis than froin actual constitutional principle. ${ }^{224}$

It does not follow froin the inere proposition that prior congressional authorization should not be required before the President deploys U.S. military forces in LIC that congressional influence on such decisions is rendered impotent. While the President may have the prerogative to commit U.S. military forces to LIC, the potential for the ultimate authority of Congress to terminate or alter such a mission serves as a practical check on presidential decisionmaking. Thus, for example, President Reagan and other members of his administration realized that any deployment of military forces in LIC would need either to be brief, such as the intervention im Grenada and retahatory strike on Libya, or to have

221. See infra notes $227-30$ and accompanying text.

222. See supra notes 77-79 and accompanying text.

223. It has been noted that the "ambiguity of low-intensity conflict guarantees some degree of domestic opposition to any form of American involvement." Metz, supra note 16, at 14. However, decisions regarding U.S. involvement in LIC must be made despite the lack of national unity. While congressional reaction should be an important factor in the presidential decisionmaking process, a decision should not be held up by the mere fact of congressional inaction.

224. Turner, supra note 213 , at 111. Turner provides two interesting examples of congressional responses to President-initiated LIC. The first incident was the reaction to the 1980 failed rescue mission of U.S. hostages held in Iran. In its aftermath, the chairmen and ranking minority members of the House and Senate foreign affairs committees declared that President Carter's rescue operation had violated the War Powers Resolution. Id. at 112. The second incident was the 1983 intervention into Grenada. Immediately after Operation Urgent Fury became public, House Speaker Tip O'Neill denounced the mission as violating the War Powers Resolution, and hearings were organized to examine its legality. However, after overnight polls showed that the U.S. public overwhelmingly supported the operation, Speaker O'Neill announced that having "reconsidered" the action, he concluded that the operation was "justified," and the hearings were "postponed" indefinitely. Id. 
the lack of clear involvement in sustained combat, such as the imterventions in Central America, im order to avoid significant congressional and political opposition to such policies. ${ }^{225}$

Congress can also significantly influence presidential discretion to use prerogative with respect to LIC by both reflecting and influencing public opinion. Since the President, as a nationally elected figure, generally factors public opimon into account before making a major decision, public opposition to a LIC could cause it to be abandoned or sliarply modified. Congress, both as a body and as individual members, has the political, as opposed to constitutional, ability to require the President to justify involvement in a LIC, sucl as by debating whether a proposed or recently executed action passes the "six tests" for the use of military force developed by former Secretary of Defense Caspar Weinberger. ${ }^{226}$

Furthermore, if Congress truly desires to ordain U.S. pohicy towards a particular LIC situation, the enactment of specific congressional legislation addressing that situation is a feasible alternative. For instance, Congress could authorize only certain limitations on executive action, such as it did in the undeclared naval war witl France at the turn of the nineteenth century. ${ }^{227}$ More recently, Congress has exercised legislation to limit U.S. mvolvement in LIC actions in Lebanon and Angola. ${ }^{228}$ The passage of such legislation demonstrates that Congress is capable of successfully opposing the President regarding LIC when there is a credible

225. SMYRL, supra note 183 , at 96.

226. Weinberger's six tests, outlined in 1984, for determining when a situation requires the United States to commit military force to combat are whether

1. U.S. vital interests are at stake.

2. The issues involved are so important for the future of the United States and

its allies that the United States is prepared to commit enough forces to win.

3. There are clearly defined political and military objectives that nust be secured.

4. U.S. forces have been properly sized to achieve U.S. objectives.

5. There is some reasonable assurance of the support of the Anerican people.

6. U.S. forces are committed to conibat only as a last resort.

WEINBERGER, supra note 99, at 402; see also id. at 441-42 (elaborating on each test).

227. See supra notes 91-97 and accompanying text.

228. See SMYRL, supra note 183 , at 54-55 (describing a series of congressional anendInents that prohibited after 1976 the spending of any funds on covert operations during the civil war in Angola); Congressional Hearings, supra note 89, at 23 (cominenting on the passage of the congressional resolution capping the deployment of U.S. Marines in Beruit at 18 months). 
alternative policy. ${ }^{229}$ Thus, presidential prerogative would serve to encourage Congress to develop alternative policies; under a constitutional structure in which congressional authorization was a prerequisite to LIC action, Congress could easily set "no policy" for the United States by refusing to approve the President's proposals while failing to put forth any of its own. ${ }^{230}$

\section{Implications of Presidential Prerogative Regarding LIC}

The adoption of a rule upholding the constitutionality of presidential prerogative with respect to LIC in the absence of an exphicit congressional mandate to the contrary would require Congress to initiate proactive measures in order to terminate or prevent U.S. involvement in a LIC. Since the legislation would be passed by Congress as a bill or joimt resolution, it would not run afoul of the legislative veto provision struck down by the Supreme Court. $^{231}$ Furthermore, requiring congressional action through legislation would be inore representative of national opinion on U.S. mvolvement in a particular LIC than would mere congressional complaints of executive branch transgressions on the separation of powers.

In other words, presidential prerogative would force Congress to debate the substantive merits of the use of military force as opposed to procedural questions of constitutional law. ${ }^{232}$ Moreover, presidential prerogative would not infringe on Congress's ability to preemptively prohibit policy choices that involve military actions, since the prerogative would be effective only in the absence of clear and exphicit legislation to the contrary of President's wishes. Thus, the rule would not be subject to the same criticism

229. See SMYRL, supra note 183, at 138-39.

230. In other words, Congress should not be able to use a questionable interpretation of the Constitution (i.e., that a President must receive congressional authorization prior to using military force abroad in LIC) as a substitute for its political failure to pass legislation denying or limiting certain action. See Koh, supra note 151, at 1304-05.

231. See INS v. Chadha, 462 U.S. 919, 959 (1983). But this in turn may require a two-thirds vote of Congress in order to terminate U.S. involvement in a LIC, since presumably the President would veto any legislation requiring a withdrawal.

232. Thus, Congress would no longer be able to use the debate over war powers as a shield against discussing the actual merits of a LIC operation; the Framers of the Constitution never intended the separation of powers to serve as "an expedient political insurance policy for the legislative branch." P.X. Kelley \& Robert F. Turner, Out of Harm's Way; From Beirut to Haiti, Congress Protects Itself Instead of Our Troops, WASH. PoST, Oct. 23, 1994, at C2. 
as the War Powers Resolution, to the extent that Congress would largely be precluded from taking preemptive action against a LIC operation and would be forced to take only remedial action once involvement had begun. 233

Furthermore, in inany cases, the developinent of a policy option of deploying military forces into a LIC can be foreseen months, if not years, in advance of the actual deployment of such forces. $^{234}$ Thus, Congress should generally have sufficient time to proffer the appropriate legislation, if it chooses to do so; presidential authority to use a broad range of mstruments in its conduct of foreign affairs, including the use of military force, should not be restricted without the passage of such legislation. In fact, it is not uncommon for presidential decisions on the deployment of U.S. military forces in LIC to be partially im response to requests by individual inembers of Congress or in liglit of the passage of nonbinding congressional resolutions. ${ }^{235}$ Furthermore, if Congress were truly concerned with playing a significant role in the pohicyformation process, it could enact "fast-track" procedures to permit the expedited consideration of legislation concerning inilitary deployinents. ${ }^{236}$ On the other hand, the rare cases when there is not sufficient time for Congress to consider an issue represent precisely the situations im which presidential prerogative is crucial: U.S. policy needs to be determined and impleinented and only the

233. See, e.g., EAGLETON, supra note 105, at 203-25.

234. For instance, the interventions in Panama in December 1989, in Somalia in December 1992, and in Haiti in September 1994 have been among the more controversial presidential deployments of military forces into LIC in recent years. Yet, in all three instances, there appears to have been sufficient time for Congress to have acted if it had so desired.

235. For example, in authorizing the U.S. intervention and the deployment of military forces in Somalia, President Bush stated,

I have taken these actions pursuant to my constitutional authority to conduct our foreign relations and as Commander in Chief and Chief Executive, and in accordance with applicable treaties and laws. In doing so, I have taken into account the views expressed in H. Con. Res. 370, S. Con. Res. 132, and the Horn of Africa Recovery and Food Security Act, Public Law 102-274, on the urgent need for action in Somalia.

Letter to Congressional Leaders on the Situation in Somalia, 28 WEEKLY COMP. PRES. Doc. 2338, 2339 (Dec. 10, 1992).

236. See, e.g., 50 U.S.C. $\$ \S 1545-1546$ (1988) (creating legislative priority procedures for joint resolutions, concurrent restitutions, and bills under the War Powers Resolution); 19 U.S.C. \& 2432(d)(2) (1988) (establishing congressional procedures under the JacksonVanik amendment to the Trade Act of 1974, Pub. L. No. 93-618, 88 Stat. 1978, 2057-60, to force a floor vote by prohibiting resolutions to overturn presidential waivers of mostfavored nation status to Communist countries from being blocked in committee). 
President has the speed and abihity to execute in a timely fashion. 237

Presidential prerogative in LIC would increase the chance that the United States might becoine involved in prolonged hostilities. This risk, however, must be balanced against constraints on U.S. flexibility to respond to rapidly changing threats in a global environment. Furthermore, one must also be concerned about the risk of failing to take action and the resulting effects on U.S. foreign relations. In short, while presidential prerogative in the area of LIC would greatly enhance the power of the executive branch, that authority could be placed in check by Congress through a variety of means other than prior authorization, such as specific legislation, oversight hearings, and reporting requirements. This interpretation of the separation of powers not only is the best approach towards the implementation of LIC in the future but also is consistent with the Constitution and caselaw.

\section{An Example of Presidential Prerogative: Haiti and Operation Uphold Democracy}

In Septeinber 1994, U.S. military forces prepared to make forced entry onto the Caribbean island of Haiti under the authority of President Clinton pursuant to U.N. Security Council Resolution $940 .{ }^{238}$ The purpose of this LIC was to neutralize "the inost violent regime in our hemisphere" and "to restore democratic government in Haiti." 239 Ultimately, the invasion was averted, as a diplomatic solution was negotiated with the military dictators who had controlled Haiti since overthrowing the previous delnocratically elected government. In summarizing the diplomatic process, President Chinton stated,

237. For instance, in 1989, several factions of the Philippine military staged an attempted coup against the Aquino government. A possibility existed that the rebel forces had access to military aircraft that were capable of bombing the Presidential Palace in Manila. In the United States, a decision whether to intervene and support the Aquino government had to be made without delay. The United States decided to support the Aquino government, and several U.S. Air Force F-4 Phantom II fighter jets were launched from Clark Air Base in the Philippines to provide coinbat air patrol and to deter any airborne threat froin the rebels. See BOB WOODWARD, THE COMMANDERS 146-52 (1992).

238. SCOR Res. 940, U.N. SCOR, 49th Sess., U.N. Doc. S/RES/940 (1994).

239. President Clinton Delivers Televised Address to the Nation on the Situation in Haiti, Federal News Service, Sept. 15, 1994, available in LEXIS, News Library, Fednew File. 
I want ... to thank the men and women of the United States armed forces. It was their presence and their preparations that played a pivotal part in this agreement. ... It is clear ... that this agreement only came because of the credible and imminent threat of the multimational force. ${ }^{240}$

Despite the apparent peaceful resolution of the Haitian crisis, which allowed the entry of U.S. military forces onto the island nation, many constitutional scholars still expressed concern that President Clinton, by failing to obtain congressional authorization, had intended to violate the separation of powers if the military invasion had taken place as planned. ${ }^{241}$ The planned invasion, involving nearly 18,000 military personnel, would have been the largest airborne assault by the United States since World War II. ${ }^{242}$ Military planners had worked for months to design a multiservice, forced-entry assault that could rapidly neutralize Haitian police and military units by using overwhelming force. ${ }^{243}$ Heavily armed AC-130 gunships and A/OA-10 attack aircraft were to provide air support for the ground forces. ${ }^{244}$

In justifying its original plans for forced entry into Haiti, the Clinton administration adopted an interpretation of the war powers that implicitly supported a prerogative, at least with respect to LIC, for the President. Secretary of State Warren Christopher stated that the President had "a constitutional prerogative" to deploy U.S. military forces because "[t]he President may have to act in a

240. Oval Office Address, supra note 212.

241. Letter from constitutional law scholars to President Clinton (Aug. 31, 1994) (on file with author); Letter from constitutional law scholars to Walter Dellinger, Assistant Attorney General, Office of Legal Counsel (Oct. 14, 1994) (on file with author). The "constitutional law scholars" who signed the letters were a group of ten law professors: Bruce Ackerman (Yale), Abrain Chayes (Harvard), Lori Damrosch (Columbia), John Hart Ely (Stanford), Gerald Gunther (Stanford), Louis Henkin (Columbia), Harold Hongju Koh (Yale), Philip B. Kurland (Chicago), Laurence H. Tribe (Harvard), and William Van Alstyne (Duke).

242. David A. Fulghum, Massed Airborne Forces Aimed at Heart of Haiti, AviATION WK. \& SPACE TECH., Oct. 10, 1994, at 71. The largest prior airborne mission occurred in the Battle of Arnhem, also known as Operation Market Garden, which took place 50 years earlier in 1944, and only partially achieved its goal of securing bridges from Nazi forces for advancing Allied ground forces. See generally CORNELIUS RYAN, A BRIDGE TOO FAR (1974) (detailing the plans of Operation Market Garden and its subsequent execution).

243. James Kitfield, The Move to Haiti, Gov'T EXECUTIVE, Nov. 1994, available in LEXIS, News Library, Mags File.

244. Fulghum, supra note 242 , at 72. 
situation very quickly and on his own constitutional authority."245 U.S. Ambassador to the Uinited Nations Madeleine Albright compared the proposed invasion of Haiti, and the requisite lack of congressional authorization, to previous U.S. actions in Grenada and Panama, as opposed to Operation Desert Storm. ${ }^{246}$ The Justice Department's Office of Legal Counsel argued that the President did not need prior congressional authorization because "after examining the circumstances, nature, scope and duration of the anticipated deployment, [the Department] determined that [the Haiti operation] was not a 'war' in the constitutional sense."247

The action of President Clinton regarding Haiti serves as a paradigm for arguing that the President has a constitutional prerogative for introducing U.S. forces in LIC. First, despite months of advance warning of possible military action, Congress intentionally decided not to take legislative action, thus inviting independent presidential action. ${ }^{248}$ Second, the application of mihtary power in a LIC situation was instrumental in forcing a diplomatic solution to the situation in Haiti, which otherwise would have not occurred. ${ }^{249}$ Third, the President acted in a manner that he had

245. Neil A. Lewis, Clinton Has Authority He Needs to Invade Haiti, Top Aides Say, N.Y. TIMES, Sept. 12, 1994, at A1.

246. Id.

247. Letter from Walter Dellinger, Assistant Attorney General, Office of Legal Counsel, to Senators Robert Dole, Alan K. Simpson, Strom Thurmond, and William S. Cohen (Sept. 27, 1994) [hereinafter Letter to Senators] (on file with author). However, the Jus. tice Department also relied on two other reasons why congressional authorization was not required: (1) Congress, as expressed by the Department of Defense Appropriations Act of 1994, Pub. L. No. 103-139, \& 8147, 107 Stat. 1418, 1474 (1993), had given broad discretion to the President, thereby inviting independent presidential responsibility; and (2) the planned deployment satisfied the War Powers Resolution. Id.

248. On July 21,1994 , nearly two months prior to the Haiti operation, a bipartisan group of House representatives announced that over 100 inembers had signed a letter to the President requesting him to seek congressional authorization prior to the commitment of U.S. military forces. News Conference with Representative David E. Skaggs (D.CO), Representative Sherwood Boehlert (R-NY), Representative Richard J. Durbin (D-IL) and Others Re: Military Action Against Haiti, Federal News Service, July 21, 1994, available in LEXIS, News Library, Fednew File. Thus, Congress had ample time to schedule debate and pass legislation authorizing or prohibiting the President from taking certain actions. The fact that the congressional leadership specifically blocked any vote or debate from taking place until after U.S. troops had landed should, rather than prohibiting the President from committing forces, have served as an acquiescence to the President's policy. See Peter W. Rodman, Leaping into Haiti Without a Safety Net, N.Y. TimES, Sept. 17, $1994, \S 1$, at 23.

249. Former President Carter, the leader of the U.S. delegation that successfully negotiated the departure of the Haitian military rulers, stated, 
determined was in the best economic and security interests of the United States (i.e., primarily to head off possible increased problems of Haitian refugees emigrating to Florida) ${ }^{250}$ Fourth, the incident demonstrates the difficulty of usmg the defensive/offensive approach to war powers as opposed to a precedent- and factorbased analysis that examines the intensity level of a conflict. ${ }^{251}$

\section{CONCLUSION}

The Haitian intervention is an example of the type of military operation that is occurring with increasing frequency in the new world order. In the quest for global imfluence in the post-Cold War era, LIC is becoming a more important imstrument and doctrine in the conduct of foreign relations. LIC actions occupy a gray area on the spectrum of conflict, representing a state that is neither peace nor war. Because LIC, if it is to be executed successfully by the United States, requires a combination of military and diplomatic efforts, the requisite authority to conduct such operations should reside in the President as a prerogative of the executive branch without requiring prior congressional authorization. Prerogative in the area of LIC, as demonstrated by this Note, is an appropriate interpretation of the Constitution that can be readily reconciled with the original intent of the Framers, with historical and customary use of force by the President, and with judicial decisions.

The key to our success, to the extent it is successful, was the inexorability of the entry of the forces into Haiti, and we spent the first hours of discussion with the military leaders to convince them that this was going to happen, it would be with an overwhelming capability, and that the schedule was set .... And it was that mevitability that was a major factor in their decision.

News Conference Conceming Haiti, Federal News Service, Sept. 19, 1994, available in LEXIS, News Library, Fednew File. In fact, the diplomatic agreement was not made until "after Haiti received evidence that paratroopers from our 82 nd airborne division, based at Fort Bragg, North Carolina, had begun to load up to begin the invasion. ... Indeed, at the time that the agreement was reached, 61 American planes were already in the air." Oval Office Address, supra note 212.

250. One journalist summarized opponents' criticism of the security reasons for the operation given by the Clinton administration as that "Haiti is a dagger pointed at the heart of Dade County[, Florida]." George J. Cluurch, Destination Haiti, TIME, Sept. 26, 1994, at 20, 25.

251. See Letter to Senators, supra note 247 , at $6-7$. The defensive/offensive approach would fail in Haiti because the President theoretically could argue that an "offensive" war does not occur when U.S. military forces enter a country at the invitation of the legitimate government of that country. 
Presidential prerogative to deploy U.S. military forces and to engage im LIC means that such authority may be restricted by Congress. However, such limitations may occur only with the passage of exphicit legislation by Congress, and in the absence of such congressional action, the initiative remains with the President. ${ }^{252}$ Since the withdrawal of U.S. forces from Vietnam, Congress has used the War Powers Resolution as convement political cover for challenging U.S. military deployments on constitutional grounds rather than on their actual merit. Prerogative thus requires Congress to debate the substantive merits of policy in order to enjoin the presidential use of force in LIC.

252. For instance, as of February 1995, Congress was considering specific legislation that would affect the President's prerogative to deploy U.S. military forces in LIC under certain circumstances. See S. 5, 104th Cong., 1st Sess. (1995) (proposed "Peace Powers Act of 1995"); H.R. 7, 104th Cong., 1st Sess. (1995) (proposed "National Security Revitalization Act"). The House legislation proposed to limit the authority of the President to deploy U.S. military forces if such forces would be placed under the command or operational control of a foreign national acting on behalf of the United Nations. The Senate legislation, though worded differently, sought to achieve the same objective: to limit the President's ability to deploy U.S. military forces in U.N.-controlled peacekeeping activities. In response to such legislation, President Clinton declared that such restrictions are "unacceptable" and represent an "infringement on the President's constitutional authority." Clinton Repeats Veto Threat, UPI, Feb. 18, 1995, available in LEXIS, News Library, Wires File (quoting President Clinton's weekly radio address). Under a theory of concurrent authority and presidential prerogative, however, congressional legislation specifically intended to bimit the President's ability to deploy military forces in LIC, such as in a U.N. operation, would be constitutional. Whether such legislation represents sound public policy is a separate question that does not involve the constitutional separation of powers. 